University at Buffalo School of Law

Digital Commons @ University at Buffalo School of Law

$11-4-2021$

\title{
The Illiberalization of American Election Law: A Study in Democratic Deconsolidation
}

James A. Gardner

University at Buffalo School of Law

Follow this and additional works at: https://digitalcommons.law.buffalo.edu/journal_articles

Part of the Constitutional Law Commons, Election Law Commons, Law and Politics Commons, and the Supreme Court of the United States Commons

\section{Recommended Citation}

James A. Gardner, The Illiberalization of American Election Law: A Study in Democratic Deconsolidation, 90 Fordham L. Rev. 423 (2021).

Available at: https://digitalcommons.law.buffalo.edu/journal_articles/1034

\section{C) ${ }_{\text {COPYRIGHT }}^{\text {N }}$}

This Article is brought to you for free and open access by the Faculty Scholarship at Digital Commons @ University at Buffalo School of Law. It has been accepted for inclusion in Journal Articles by an authorized administrator of Digital Commons @ University at Buffalo School of Law. For more information, please contact lawscholar@buffalo.edu. 


\title{
THE ILLIBERALIZATION OF AMERICAN ELECTION LAW: A STUDY IN DEMOCRATIC DECONSOLIDATION
}

\author{
James A. Gardner*
}

For many years, the dominant view among American election law scholars has been that the U.S. Supreme Court's constitutional jurisprudence of democratic practice got off to a promising start during the mid-twentieth century but has since then slowly deteriorated into incoherence. In light of the United States' recent turn toward populist authoritarianism, that view needs to be substantially revised. With the benefit of hindsight, it now appears that the Supreme Court has functioned, in its management of the constitutional jurisprudence of democracy, as a vector of infection-a kind of super-spreader of populist authoritarianism.

There is, sadly, nothing unusual these days about an apex court reinterpreting a formerly liberal constitutional jurisprudence to support a populist authoritarian regime. Typically, however, constitutional courts pivot toward authoritarianism suddenly, after they have been captured through aggressive court-packing or coercive threats and intimidation. In the United States, however, federal courts retain real independence, and the process of illiberalization has been correspondingly slower and less immediate. In particular, the Supreme Court has slowly illiberalized American election law in a two-stage process: first, by deconsolidating a liberal jurisprudence into incoherence and then by reconsolidating it into a form more conducive to authoritarianism. The main strategy by which this has occurred has been an increasingly aggressive deployment of an ever-narrower palette of individual rights, gradually narrowing a complex and conceptually rich jurisprudence to a single dimension-a judicial strategy that, in its radical anti-pluralism, is deeply populist, fundamentally illiberal, and profoundly destructive of the inherited liberal democratic settlement of the late twentieth century.

\footnotetext{
* Bridget and Thomas Black SUNY Distinguished Professor of Law and Research Professor of Political Science, University at Buffalo School of Law, The State University of New York. This Article was prepared for the Symposium entitled Toward Our 60th Presidential Election, hosted by the Fordham Law Review on February 26, 2021, at Fordham University School of Law. My thanks to Matt Steilen and Anya Bernstein for helpful conversations and comments.
} 
INTRODUCTION

I. THE VIEW From THERE: THE JURISPRUDENTIAL DRIFT INTO INCOHERENCE 427

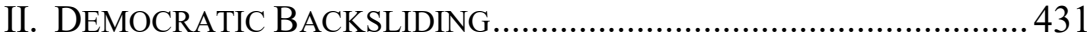

III. THE ARC OF ILLIBERALIZATION ................................................... 435

A. Beginnings: Liberal and Plural....................................... 436

1. The Raw Material of the Constitutional Scheme ....... 436

2. The Founding Jurisprudence: Pluralist and Liberal .. 438

B. Deconsolidation into Incoherence .................................. 440

1. The Move to Rights: Three Regimes ........................ 440

a. Regime 1: Racial Discrimination........................ 440

b. Regime 2: The Equal Protection-Based Right to

Vote.............................................................. 442

c. Regime 3: The Catch-All First Amendment ........ 444

2. The Scholarly Critique .............................................. 449

C. Reconsolidation: The Path to Illiberalism ..................... 452

1. Jurisprudential Exile: Narrowing the Field of Relevant

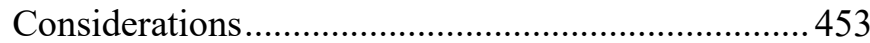

a. The Gag Rule ........................................................ 453

b. The Rights That Don't Exist................................ 454

c. The Claims That Don't Exist................................ 456

d. No One Has Standing............................................ 456

2. Selective Vigor in Deploying Recognized Rights ..... 457

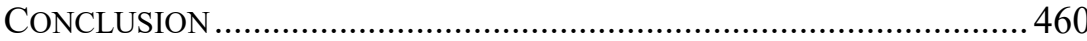

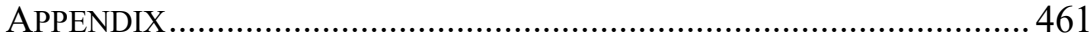

\section{INTRODUCTION}

Sometimes we don't fully understand where we're headed until we arrive. In those moments, gazing back along the route we've traveled, things can look very different from how they appeared during the journey.

For many years, the dominant view among American election law scholars has been that the U.S. Supreme Court's constitutional jurisprudence of democratic practice got off to a promising start during the mid-twentieth century but has, over the last several decades, slowly deteriorated into incoherence. There it has remained, festering, unable to perform competently the minimal tasks that a democratic people demands from its own basic constitutional framework. Most scholars even agree on the cause: a disastrous methodological choice by the Supreme Court to look to individual rights rather than constitutional structure as the principal-indeed, 
the virtually exclusive - source of constitutional guidance on questions of democratic practice. ${ }^{1}$

That view, I will argue here, was not wrong when it emerged, but in light of recent events it must be substantially revised, for it was the view of the traveler, a snapshot taken en route, when we still did not know where we were headed. Now we know. For nearly a quarter of a millennium, what Americans thought they knew about themselves is that the United States was a liberal republic founded on the principle of popular self-rule 2 and that its history has unfolded, if not in one long, steady march toward a perfected democracy, at least along a serpentine path leading in that general direction, 3 guided by a broad societal consensus that a perfected democracy was our final destination as a people. In 2016, Americans tore themselves from that dream by electing to the presidency, for the first time, a populist authoritarian 4 who, with the full support of one of the two major national parties, 5 waged a four-year war not only on democracy but also on the philosophical liberalism on which it rests.

From this vantage point, things look very different, and my goal here is to retell the story of American election law in a way informed by an understanding only recently made possible by the unwelcome realization, afforded with the benefit of hindsight, that right-wing populist authoritarianism may long have been our at least partially unwitting destination. In this story, the Supreme Court has not been a naive or heedless producer of doctrinal incoherence. On the contrary, it is now clear that the Supreme Court has functioned, in its management of the constitutional jurisprudence of democracy, as a vector of infection, a kind of super-spreader of the conditions in which populist authoritarianism may take root and thrive.

What makes this story unusual is not, however, that an apex court has moved to replace a formerly liberal constitutional jurisprudence with one more congenial to populist authoritarianism. Sadly, democratic backsliding has become so commonplace around the world in the last decade that this is exactly what has occurred in many regimes. ${ }^{6}$ Typically, however, constitutional courts pivot toward authoritarianism only after they have been captured by a newly installed authoritarian regime - most often following aggressive deployment of policies to replace incumbent judges, pack the court with new appointees, or coerce favorable rulings through threats and

1. See infra Part III.B.2.

2. See generally Louis Hartz, The Liberal Tradition in America: AN Interpretation of American Political Thought Since the Revolution (1955).

3. See Alexander Keyssar, The Right to Vote: The Contested History of DEMOCRACY IN THE United STATES xvii-xviii, xx (2000).

4. See Steven Levitsky \& Daniel Ziblatt, How Democracies Die 2 (2018); Pippa Norris \& Ronald Inglehart, Cultural Backlash: TrumP, BreXit, AND Authoritarian POPULISM 245-46 (2019).

5. See LeVITSKY \& Ziblatt, supra note 4, at 69, 70, 201.

6. See generally David Landau \& Rosalind Dixon, Abusive Judicial Review: Courts Against Democracy, 53 U.C. DAVIS L. REV. 1313 (2020). 
intimidation. ${ }^{7}$ The hallmark of this kind of jurisprudential pivot is the suddenness with which it occurs.

Conditions in the United States, however, are different. Even today, federal courts retain real independence, reinforced by powerful norms of judicial branch autonomy, the ready availability of a robust veto tool, and a long history of willingness to use it in self-defense. 8 As a result, the illiberalization of American election law has not occurred according to the emerging template. It has instead occurred much more slowly and has been driven largely by the Supreme Court itself rather than by a powerful, authoritarian chief executive demanding judicial fealty. As a result, the jurisprudence has evolved incrementally in roughly two major stages. In the first stage, the Court took a robust liberal jurisprudence of democracy and deconsolidated it, rendering it, as so many scholars have observed, incoherent. In hindsight, however, we can now see that incoherence was not a destination but merely a temporary waypoint, for it was followed closely by a second stage of jurisprudential development in which the Court began to reconsolidate the constitutional jurisprudence of democracy along illiberal lines. ${ }^{9}$

The Court's main strategy throughout this process has been simple and consistent: it has pressed, with increasing aggressiveness, an ever-narrower palette of constitutional rules, to the point where a constitution initially well-stocked with provisions and principles relating to democratic practice was gradually remade by the Court into one that is textually bare and conceptually impoverished. Today, the Court has reached the point where it typically views only one provision in the entire Constitution - the First Amendment, seven words out of thousands - as relevant to the resolution of constitutional issues of democratic self-governance.

Political theorists agree that the defining characteristic of modern populism is its deep aversion to political pluralism, 10 and in this sense, the Court's strategy has been straight out of the populist playbook. By gradually stripping the Constitution's rich, multidimensional conception of democracy

7. See id. at 1338-45. See generally David Kosař \& Katarína Šipulová, How to Fight Court-Packing?, 6 CONST. STUD. 133 (2020).

8. This is seen, for example, in the decisive rejections by federal courts of Trump campaign challenges to results of the 2020 presidential election. See Rosalind S. Helderman \& Elise Viebeck, "The Last Wall": How Dozens of Judges Across the Political Spectrum Rejected Trump's Efforts to Overturn the Election, WASH. Post (Dec. 12, 2020, 2:12 PM), https://www.washingtonpost.com/politics/judges-trump-electionlawsuits/2020/12/12/e3a57224-3a72-11eb-98c4-25dc9f4987e8_story.html [https://perma.cc/PQ5H-AA5E].

9. In proposing a two-stage process, my analysis has much in common with that of Landau's Populist Constitutions, except Landau deals with the more common situation in which a liberal constitution is deconsolidated and then reconsolidated primarily by textual amendment and replacement. See David Landau, Populist Constitutions, 85 UNIV. CHI. L. REV. 521 (2018). Here, the process I describe involves almost exclusively an apex court's superintendence of a constitutional document, the text of which remains stable.

10. See Jan-Werner Müller, What Is Populism? 25 (2016); Nadia Urbinati, Me the People: How Populism Transforms Democracy 91 (2019). See generally William A. Galston, Anti-Pluralism: The Populist Threat to Liberal Democracy (2018). 
down to a single concept - freedom of speech — the Court has shaped a jurisprudence that is much more than merely incoherent. It has become populist, pro-authoritarian, and hostile to liberal democracy; it has become a kind of anti-election jurisprudence that is fundamentally illiberal and deeply destructive of the inherited liberal settlement of the late twentieth century. The problem, in other words, is not the Court's incoherence; it is the Court's illiberalism.

This Article will make good on these claims in the following way. Part I provides a brief introduction to the problem that has long concerned scholars of election law: the slow descent of the constitutional jurisprudence of democracy into incoherence. Part II offers a quick review of global trends and patterns of democratic backsliding in liberal democracies, focusing on the role of courts. Part III carefully traces the arc of the Supreme Court's election jurisprudence, showing its evolution from liberalism to a deconsolidated incoherence to what is, at present, a slowly consolidating illiberalism.

\section{THE VIEW FROM THERE: THE JURISPRUDENTIAL DRIFT INTO INCOHERENCE}

After 170 years of near dormancy, the issue of constitutional management of democracy burst into the public consciousness in the 1960s following a series of Supreme Court decisions that profoundly altered the way Americans practice democratic self-governance. In the space of a single decade, the Court invoked the U.S. Constitution to invalidate long-standing practices of racial gerrymandering 11 and malapportionment of election districts at the federal, 12 state, 13 and local levels. ${ }^{14}$ It decimated time-honored voter eligibility requirements based on residency, 15 duration of residency, ${ }^{16}$ payment of poll taxes, ${ }^{17}$ and property ownership. 18 It struck down obstacles to electoral candidacy, invalidating state-imposed ballot access requirements relating to signatures, ${ }^{19}$ filing fees, ${ }^{20}$ and possession of property. ${ }^{21}$ It tore through restrictions on the way campaigns are conducted, upending bans on election day campaigning 22 and restrictions on criticism of incumbent public

11. Gomillion v. Lightfoot, 364 U.S. 339, 347-48 (1960).

12. Wesberry v. Sanders, 376 U.S. 1, 16-18 (1964).

13. Reynolds v. Sims, 377 U.S. 533, 584 (1964).

14. Avery v. Midland Cnty., 390 U.S. 474, 497 (1968). The Court also went on to invalidate malapportionment in many kinds of special districts. See, e.g., Hadley v. Junior Coll. Dist., 397 U.S. 50, 58-59 (1970); Cipriano v. City of Houma, 395 U.S. 701, 705-06 (1969).

15. Carrington v. Rash, 380 U.S. 89, 96-97 (1965).

16. Dunn v. Blumstein, 405 U.S. 330, 360 (1972).

17. Harper v. Va. Bd. of Elections, 383 U.S. 663, 670 (1966).

18. Kramer v. Union Free Sch. Dist. No. 15, 395 U.S. 621, 622, 633 (1969).

19. Williams v. Rhodes, 393 U.S. 23, 60-61 (1968). (1972).

20. Lubin v. Panish, 415 U.S. 709, 718-19 (1974); Bullock v. Carter, 405 U.S. 134, 149

21. Turner v. Fouche, 396 U.S. 346, 364 (1970).

22. Mills v. Alabama, 384 U.S. 214, 220 (1966). 
officials. ${ }^{23}$ And it decisively upheld the single most significant congressional intervention in the history of American civil rights, ${ }^{24}$ the Voting Rights Act of 1965 (VRA), which itself set aside well-established principles of federalism by subordinating state electoral practices to direct federal oversight. 25

During this run, the Court began to build and deploy a rich and deeply liberal constitutional jurisprudence of democratic practice that dismantled long-standing barriers to participation by the politically marginalized, including Black people, city residents, the poor, and political dissenters. ${ }^{26}$ In so doing, it smashed and discarded old practices, holding out to the American public the possibility of new regulatory regimes that promised not just electoral fairness, but the systematic, mindful pursuit of democratic goals in place of reflexive obedience to inherited practice and passive acquiescence in long-standing power structures.

Then things got weird.

After a decade of breaking down barriers to participation by the politically weak, the Court began to apply the same aggressive skepticism to regulatory measures meant to prevent domination of the political process by the powerful. In Buckley v. Valeo, 27 a controversial 1976 ruling, 28 the Court started down this path by holding not only that the Constitution does not implicitly contain, or even look favorably upon, any principle of equality of political influence among citizens, but that it is in fact actively opposed to such a principle, even as an ideal.29 The Court used this holding as the launching pad for a forty-year march through measures attempting to control political spending, during which it invalidated regulatory caps on total campaign spending by candidates; 30 contributions by rich candidates to their own campaigns; 31 and independent campaign expenditures by private individuals, 32 political parties, 33 political committees, 34 advocacy organizations, 35 and, in its 2010 ruling in Citizens United $v$. FEC, 36 for-profit corporations. 37

23. N.Y. Times Co. v. Sullivan, 376 U.S. 254, 292 (1964)

24. South Carolina v. Katzenbach, 383 U.S. 301, 337 (1966).

25. Pub. L. No. 89-110, 79 Stat. 437 (codified as amended in scattered sections of 52 U.S.C.).

26. See John Hart Ely, Democracy and Distrust: A Theory of Judicial Review (1980).

27. 424 U.S. 1 (1976) (per curiam).

28. For an overview of critiques of Buckley, see JAMES A. GARDNER \& GUY-URIEL Charles, Election Law in the American Political System 759-66 (2d ed. 2018).

29. See Buckley, 424 U.S. at $48-49$.

30. Id. at 54-59.

31. Id. at $51-54$.

32. Id. at $39-51$.

33. Colo. Republican Fed. Campaign Comm. v. FEC (Colorado Republican I), 518 U.S. 604, 624-26 (1996).

34. FEC v. Nat'l Conservative Pol. Action Comm., 470 U.S. 480, 500-01 (1985).

35. FEC v. Mass. Citizens for Life, Inc., 479 U.S. 238, 263-65 (1986).

36. 558 U.S. $310(2010)$.

37. Id. at 365 . 
The Court also began to decide cases in ways that produced bizarre and inexplicable outcomes. It held, for example, that the Constitution prohibits limitations on political spending but permits restrictions on political contributions, 38 thereby creating a system of campaign finance in which the demand for political money is unlimited and insatiable, but the supply of it is highly constrained - a recipe for cheating and corruption. ${ }^{39}$ In the field of political parties, the Court held that the Constitution prohibits the partisan blanket primary, ${ }^{40}$ a measure adopted by several states for the seemingly uncontroversial purpose of producing more moderate candidates in an era of increasing partisan polarization. In the area of judicial elections, it ruled that the Constitution prohibits regulatory restrictions on the grounds upon, and the methods by which, judicial candidates may campaign for elective judgeships, ${ }^{41}$ obliterating a long-standing distinction between the nature of campaigns for judicial and legislative offices. This change all but forced previously civil campaigns for elective judgeships into the pattern of bitter partisanship and high spending normally associated with legislative campaigns. 42

Despite having affirmed the constitutionality of public financing of elections, ${ }^{43}$ the Court nevertheless invalidated measures providing supplemental public funding to poor candidates who face rich, self-financed ones on the ground that such measures "penalize" the rich by unfairly eliminating their resource advantage. 44 In Shelby County v. Holder, 45 the Court gutted on constitutional grounds the preclearance provisions of the VRA, 46 the centerpiece of the most successful civil rights statute in American history. In McCutcheon v. FEC 47 and McDonnell v. United States, ${ }^{48}$ the Court held that the Constitution embodies a definition of political corruption so narrow as to preclude regulation of virtually any political transaction except the most blatant exchanges of cash for power. 49 At the same time, the Court failed in four tries to develop and apply a constitutional standard to restrain one of the most pressing political problems of our time, the

\footnotetext{
38. See Buckley v. Valeo, 424 U.S. 1, 20-23 (1976) (per curiam).

39. See Samuel Issacharoff \& Pamela S. Karlan, The Hydraulics of Campaign Finance Reform, 77 TEX. L. REV. 1705, 1710-11 (1999).

40. Cal. Democratic Party v. Jones, 530 U.S. 567, 585-86 (2000).

41. Republican Party of Minn. v. White, 536 U.S. 765, 788 (2002).

42. See Money in Judicial Elections, BRENNAN CTR. FOR JUST., https:/www.brennancenter.org/issues/strengthen-our-courts/promote-fair-courts/moneyjudicial-elections [https://perma.cc/N4ZG-TPR4] (last visited Sept. 17, 2021).

43. See Buckley, 424 U.S. at 85-108.

44. Ariz. Free Enter. Club's Freedom Club PAC v. Bennett, 564 U.S. 721, 742, 754-55

(2011); Davis v. FEC, 554 U.S. 724, 740 (2008).

45. 570 U.S. 529 (2013).

46. Id. at $556-57$.

47. 572 U.S. 185 (2014).

48. 136 S. Ct. 2355 (2016).

49. McDonnell, 136 S. Ct. at 2372-73, 2375; McCutcheon, 572 U.S. at 207-10, 227.
} 
increasingly aggressive practice of partisan gerrymandering, 50 and in Rucho v. Common Cause, 51 abandoned the effort altogether. 52 And perhaps most significantly of all, the Court in Bush v. Gore ${ }^{53}$ ordered a halt to ballot recounts in the 2000 presidential election, an action that was widely, if in retrospect not entirely accurately, 54 believed at the time to have thrown the presidential race to the Republican candidate, George W. Bush.

What to make of all this? It is, of course, the stock-in-trade of scholars to criticize, yet scholarly critique of the Court's election law jurisprudence has gone well beyond professionally routine criticism of particular decisions or doctrines. In fact, there is scarcely an election law scholar working today who has not at some point declared the Court's entire body of election law decisions to be literally "incoherent," 55 or even, for lack of a more potent adjective, "beyond incoheren[t],"56 to say nothing of "muddled,"57 a "doctrinal quagmire," 58 and "utterly at sea." 59

50. See, e.g., Gill v. Whitford, 138 S. Ct. 1916 (2018); League of United Latin Am. Citizens v. Perry, 548 U.S. 399 (2006); Vieth v. Jubelirer, 541 U.S. 267 (2004); Davis v. Bandemer, 478 U.S. 109 (1986).

51. 139 S. Ct. 2514 (2019).

52. Id.

53. 531 U.S. 98 (2000) (per curiam).

54. Subsequent investigations suggest that completing the interrupted recount would not likely have changed the result. See Ford Fessenden \& John M. Broder, Examining the Vote: The Overview; Study of Disputed Florida Ballots Finds Justices Did Not Cast the Deciding Vote, N.Y. Times (Nov. 12, 2001), https://www.nytimes.com/2001/11/12/us/examining-voteoverview-study-disputed-florida-ballots-finds-justices-did-not.html [https://perma.cc/PP6A29SC].

55. See, e.g., Albert W. Altschuler, Limiting Political Contributions After McCutcheon, Citizens United, and Speechnow, 67 FLA. L. REV. 389, 445 n.281 (2015); Christopher S. Elmendorf, Structuring Judicial Review of Electoral Mechanics: Explanations and Opportunities, 156 U. PA. L. REV. 313, 349 (2007); Edward B. Foley, Election Law and the Roberts Court: An Introduction, 68 OHIO ST. L.J. 733, 735-36, 742 (2007); Luis Fuentes-Rohwer \& Laura Jane Durfee, Leaving the Thicket at Last?, 2009 Mich. ST. L. REv. 419, 421, 431-32; James A. Gardner, The Dignity of Voters-A Dissent, 64 U. Miami L. ReV. 435, 440-41 (2010); Heather K. Gerken, The Right to Vote: Is the Amendment Game Worth the Candle?, 23 WM. \& MARY BILL OF RTS. J. 11, 24 (2014); Joel Gora, The First Amendment . . . United, 27 GA. ST. L. REV. 935, 980 (2011); Richard L. Hasen, Buckley Is Dead, Long Live Buckley: The New Campaign Finance Incoherence of McConnell v. Federal Election Commission, 153 U. PA. L. Rev. 31, 32-33 (2004); Pamela S. Karlan, New Beginnings and Dead Ends in the Law of Democracy, 68 OHIO ST. L.J. 743, 761 (2007); Daniel R. Ortiz, The Informational Interest, 27 J.L. \& PoL. 663, 682 (2012); Lori Ringhand, Defining Democracy: The Supreme Court's Campaign Finance Dilemma, 56 Hastings L.J. 77, 80 (2004); Daniel P. Tokaji, Desegregation, Discrimination and Democracy: Parents Involved's Disregard for Process, 69 OHIO ST. L.J. 847, 848 (2008). As long as a decade ago, Professor Tokaji described "[t]he incoherence of the Supreme Court's election law jurisprudence" as "a recurring theme" of an entire symposium. Daniel P. Tokaji, Leave It to the Lower Courts: On Judicial Intervention in Election Administration, 68 OHIO ST. L.J. 1065, 1065 (2007).

56. See generally Richard L. Hasen, Beyond Incoherence: The Roberts Court's Deregulatory Turn in FEC v. Wisconsin Right to Life, 92 MinN. L. REV. 1064 (2008).

57. Michael S. Kang, When Courts Won't Make Law: Partisan Gerrymandering and a Structural Approach to the Law of Democracy, 68 OHIо ST. L.J. 1097, 1097 (2007).

58. Samuel Issacharoff \& Pamela S. Karlan, Where to Draw the Line?: Judicial Review of Political Gerrymanders, 154 U. PA. L. REV. 541, 574 (2004). (2007).

59. Guy-Uriel E. Charles, Democracy and Distortion, 92 CoRnell L. Rev. 601, 604 
This conclusion was, at the time, difficult to resist, and logically raised the question of what might account for the Court's slow and alarming drift into incoherence in a domain of constitutional law that, perhaps more than any other, ought to enjoy clarity and stability. For two decades, the prevailing scholarly consensus was, and remains, that the roots of the Court's difficulty lie in a methodological choice. The U.S. Constitution contains many provisions that establish and regulate processes of democratic self-rule. Some of these, like Article I, Section 2, which provides that the House of Representatives shall be "chosen every second Year by the People of the several States," and sets minimum qualifications for representatives, are structural.60 Others, like the Equal Protection Clause and the First Amendment, establish judicially enforceable individual rights. ${ }^{61}$ The problem, scholars have generally contended, is that the constitutional jurisprudence of democracy developed by the Court increasingly is founded almost exclusively on individual rights and pays virtually no attention to foundational principles of representative democracy embedded in the Constitution's structural provisions - a position that frames the so-called "rights-structure debate." 62

But that was then. Since this body of scholarly opinion emerged, much has become clear that was not clear at the time.

\section{DEMOCRATIC BACKSLIDING}

Following the conclusion of World War II, and again after the fall of the Berlin Wall in 1989, two successive waves of worldwide democratization so dramatically expanded the number of democracies in the world 63 that it seemed to some as though liberal democracy ${ }^{64}$ were the culmination of some

60. U.S. CONST. art. I, § 2 .

61. Id. amends. I, XIV.

62. Among the many works that have either made or expressed sympathy for the structural critique of the Court's rights-oriented election law jurisprudence are: Charles, supra note 59, at 649-70; Christopher S. Elmendorf, Undue Burdens on Voter Participation: New Pressures for a Structural Theory of the Right to Vote?, 35 Hastings CONST. L.Q. 643, 644 (2008); Gardner, supra note 55, at 441-42; Heather Gerken, Lost in the Political Thicket: The Court, Election Law, and the Doctrinal Interregnum, 153 U. PA. L. REv. 503, 504 (2004); Samuel Issacharoff \& Richard H. Pildes, Politics as Markets: Partisan Lockups of the Democratic Process, 50 Stan. L. Rev. 643, 646 (1998); Pamela S. Karlan, Nothing Personal: The Evolution of the Newest Equal Protection from Shaw v. Reno to Bush v. Gore, 79 N.C. L. Rev. 1345 (2001); Richard H. Pildes, Why Rights Are Not Trumps: Social Meanings, Expressive Harms, and Constitutionalism, 27 J. Legal STUD. 725, 727 (1998); Richard H. Pildes, Foreword: The Constitutionalization of Democratic Politics, 118 HARV. L. REv. 29, 40 (2004); Ringhand, supra note 55, at 87; Frederick Schauer, Judicial Review of the Devices of Democracy, 94 Colum. L. ReV. 1326, 1329-30 (1994).

63. See Samuel P. Huntington, The Third Wave: Democratization in the Late Twentieth Century 17 (1991); Joshua Kurlantzick, Democracy in Retreat: The Revolt of the Middle Class and the Worldwide Decline of Representative GOVERnMENT 35, 49-64 (2013); LARRY DiAmond, ILl WindS: SAVING DEMOCRACY From Russian RAge, Chinese AMBition, AND AMERICAN COMPLACENCY 43-53 (2019).

64. See infra Part III for discussion of the term "liberalism" and its relation to "democracy." 
kind of "natural human evolution."65 More recently, however, this trend has undergone an equally dramatic reversal. The number of states becoming less democratic has climbed steadily over the last two decades to levels not seen since the late 1970s; almost 35 percent of the world's population now lives in "autocratizing nations." 66 Moreover, even in many states that remain fundamentally democratic, the quality of democracy, as measured by the free enjoyment of civil liberties, the rule of law, and the integrity of democratic processes, has declined.67 In this process of "democratic backsliding," long-standing, stable democracies have suffered slow, incremental degradation of previously reliable democratic institutions. 68 According to Freedom House, for example, the number of "highly deficient democracies" around the world doubled between 2006 and 2010.69 In 2016, The Economist's Democracy Index downgraded the United States to a "flawed democracy." 70

The typical pattern by which democratic decline occurs also has changed dramatically from earlier periods. During the twentieth century, authoritarian takeovers typically occurred by way of a military coup or naked electoral fraud on a massive scale. ${ }^{71}$ Today, in contrast, democratic backsliding most often follows an open democratic process in which an illiberal party wins power under reasonably fair rules of democratic competition before gradually entrenching itself in power through anti-democratic means. 72

This kind of incremental democratic backsliding has by now become sufficiently commonplace to allow comparativists to identify certain common patterns by which democratically elected authoritarian leaders gradually consolidate power and undermine liberal democratic institutionsa kind of "authoritarian's playbook."73 The most typical strategy involves

65. Robert Kagan, The Jungle Grows Back: America and Our Imperiled World 61, 134 (2018); see also Francis Fukuyama, The End of History and the LAST MaN (1st ed. 1992); Helena Rosenblatt, The Lost History of Liberalism: From ANCient Rome to THE TWENTY-First CENTURY 168 (2018).

66. Seraphine F. Maerz et al., State of the World 2019: Autocratization SurgesResistance Grows, 27 Democratization 909, 909 (2020).

67. See GAlston, supra note 10, at 12; Pippa Norris \& Max Grömping, Populist Threats to Electoral Integrity: The Year in Elections, 2016-2017, at 28 (Harvard Kennedy Sch. Faculty Rsch., Working Paper No. RWP17-018, 2017).

68. Nancy Bermeo, On Democratic Backsliding, 27 J. Democracy 5 (2016); TOM Ginsburg and Aziz HuQ, How to Save a Constitutional Democracy 43-47 (2018); DIAMOND, supra note 63 , at 55.

69. KURLANTZICK, supra note 63 , at 9.

70. The ECONOMist InTELligence Unit, Democracy InDEX 2016: REVENGE OF THE "DEPLORABLES" (2016), http://www.eiu.com/Handlers/ WhitepaperHandler.ashx?fi=Democracy-Index-

2016.pdf\&mode=wp\&campaignid=DemocracyIndex2016 [https://perma.cc/4HQL-K6A3].

71. See Bermeo, supra note 68, at 6-7.

72. See id. See generally Steven LeVitsky \& Lucan A. Way, Competitive Authoritarianism: Hybrid Regimes After the COLD WAR (2010).

73. James A. Gardner, Illiberalism and Authoritarianism in the American States, 70 АM. U. L. REV. 829, 853 (2021). 
moving quickly to concentrate power in the executive, 74 which in turn entails the systematic undermining of interbranch checks on executive power. ${ }^{75}$ Where the structure of governance includes a constitutional court with the power of judicial review, this tactic requires undermining the independence of the court to the point that it becomes incapable of curbing abuses of government power. 76

In most cases of democratic backsliding, the tactics deployed to undermine judicial independence have been direct, aggressive, and initiated by an authoritarian executive, usually with the cooperation of a legislature controlled by the leader's party. These tactics include court-packing through manipulation of the size of the apex court; seizing control of the appointments process; or the use of credible, coercive threats against sitting judges. 77 The hallmark of this kind of judicial capture - and, of course, its desired outcome - is a sudden alteration in the court's jurisprudence in favor of results preferred by the regime. As Professors David Landau and Rosalind Dixon explain, a captured apex court that had previously stood up to an authoritarian regime may suddenly adopt a posture of passivity and begin to uphold legislation or executive actions that undermine core principles of democratic self-governance, insulating the ruling regime from meaningful electoral competition.78 In more extreme cases, a captured court may begin on its own actively to devise and aggressively to apply new legal doctrine that advances the authoritarian regime's agenda. 79

The characteristic evidence that such measures have successfully captured constitutional courts is a sudden shift in jurisprudence and legal reasoningthe court's methods and decisions are liberal until, suddenly and suspiciously, they are not. Thus, in Bolivia, for example, in a 2015 decision, the Bolivian high court considered a constitutional provision limiting presidential terms to be a clear and valid restriction on the ability of President Evo Morales to continue in office. 80 Following an aggressive program of court-packing, the court two years later reversed itself and, in an opinion riddled with dubious reasoning, invalidated the constitution's presidential term limits as a violation of international human rights law. 81

In the United States, democratic backsliding in the executive and legislative branches of the national government has occurred more or less

74. See Bermeo, supra note 68 , at 10-13 (discussing "executive aggrandizement"); GINSBURG \& HuQ, supra note 68, at 150-54, 178-79.

75. See GinsBURG \& HuQ, supra note 68 , at $72-73$.

76. See DiAmond, supra note 63, at 64-65; András Jakab, What Can Constitutional Law Do Against the Erosion of Democracy and the Rule of Law? 7-8 (Max Planck Inst. of Compar Pub. L. \& Int'1 L. Research Paper, Paper No. 2019-15, 2019), https://papers.ssrn.com/sol3/ papers.cfm?abstract id=3454649 [https://perma.cc/S9C7-9DAK].

77. See Kosař \& Šipulová, supra note 7, at 139-44; Landau \& Dixon, supra note 6, at 1336.

78. See Landau \& Dixon, supra note 6, at 1346-49.

79. See id. at $1349-53$.

80. Tribunal Constitucional de Bolivia [Constitutional Tribunal of Bolivia] Oct. 14, 2015, Sentencia Constitucional Plurinacional 0382/2015-CA Expediente 12664-2015-26-CPR.

81. See Landau \& Dixon, supra note 6, at 1362-63. 
according to the usual pattern. Donald Trump, a populist authoritarian candidate, 82 won the presidency in a fair and open contest, and the Republican Party, which in the wake of Trump's victory now leans decisively toward right-wing populism, 83 held and retained the Senate. Following the authoritarian playbook, Trump, with the approval and support of Republicans in Congress, ${ }^{84}$ mounted a series of attacks on the foundations of the liberal democratic state by demonizing political opponents; attacking independent institutions like the press, the judiciary, and the federal civil service; praising and encouraging white supremacists; and lying constantly. Trump ultimately attempted openly to undermine electoral democracy itself by denying his 2020 electoral defeat, and then inciting a riot at the Capitol in the hope of disrupting the constitutionally prescribed process for concluding the presidential election. 85

On the judicial side, however, the story is more complicated. To be sure, Republicans have long engaged in a highly deliberate campaign to control the judiciary including, on the state level, through overt court-packing. 86 Nevertheless, the federal judiciary is institutionally well-insulated from political pressure, and enjoys a tradition of significant judicial independence stretching all the way back to the founding era. 87 Although conditions thus exist that would allow the U.S. Supreme Court to maintain itself as a bulwark against populist and authoritarian efforts to erode liberal democracy, it simply has not done so.

However, again because of the Court's independence, the illiberalization of American election law has proceeded along a path different from the one described above, a path that has been largely under the control of the Court and which it has followed in its own way, in its own time. The process of illiberalization has thus been incremental, complex, and largely hidden from public view because it has occurred mainly through incremental changes in

82. See NorRIs \& IngLEHART, supra note 4 , at $245-46$.

83. See Robert C. Lieberman et al., The Trump Presidency and American Democracy: A Historical and Comparative Analysis, 17 PERSPS. ON POL. 470, 471 (2018); Paul Pierson \& Eric Schickler, Madison's Constitution Under Stress: A Developmental Analysis of Political Polarization, 23 AnN. Rev. Pol. SCI. 37, 53 (2020).

84. See LeVITSKy \& ZiBlatT, supra note 4, at 69-70, 201; Gardner, supra note 73, at 86367; Lieberman et al., supra note 83, at 473.

85. On President Trump's disdain for constitutional norms, see Neil S. Siegel, Political Norms, Constitutional Conventions, and President Donald Trump, 93 IND. L.J. 177 (2018); Daphna Renan, Presidential Norms and Article II, 131 HARV. L. REV. 2187 (2018); Jamal Greene, Trump as a Constitutional Failure, 93 IND. L.J. 93 (2018); see also Lieberman et al., supra note 83 , at 471 . On his refusal to accept the election results and incitement of insurrection, see H.R. Res. 24, 117th Cong., 1st Sess. (2021) (article of impeachment against President Trump).

86. See Terri Jennings Peretti, Partisan Supremacy: How the GOP Enlisted Courts to Rig America's Election Rules (2020); Steven M. Teles, The Rise of the Conservative Legal Movement: The Battle for Control of the LaW 10 (2008); Marin K. Levy, Packing and Unpacking State Courts, 61 WM. \& MARY L. REV. 1121, 1135-45 (2020).

87. Marbury v. Madison is, of course, the conventional locus classicus. See 5 U.S. 137 (1803). 
constitutional doctrine, sometimes of a highly technical nature. 88 This illiberalization has proceeded in two stages: First, the Court deconsolidated an existing liberal constitutional jurisprudence of democracy into incoherence, creating the kind of chaos and confusion in which authoritarianism is known to thrive. 89 Then, the Court began a slow process of reconsolidating the jurisprudence as illiberal and anti-democratic.

\section{THE ARC OF ILLIBERALIZATION}

This part traces in detail the development over fifty years of the Supreme Court's jurisprudence of democratic practice to show its evolution from liberal to illiberal. Before proceeding to this analysis, it is important to explain briefly what I mean by these terms.

The meaning of "liberalism" has often been deeply contested, even by its own adherents. 90 Nevertheless, contemporary writers generally agree on several core features of liberal thought. Perhaps its most basic principle is popular sovereignty - the doctrine that the people of a society are entitled to rule themselves, rather than to be ruled by some leader whose claim to rule derives from either tradition or divine command. ${ }^{91}$ The idea of popular sovereignty is conventionally associated with other commitments upon which popular sovereignty rests, or which are essential to its success. These include, for example, a commitment to the fundamental political equality of citizens; 92 the requirement of a "lively civil society,"93 in which citizens enjoy the freedom necessary to develop their own ideas about the nature of the good life and how the polity ought best to pursue it; the "rule of law";94 and, typically, a package of basic human rights, such as the rights of free speech and free association, thought necessary to the effectuation of popular self-rule. 95

Illiberalism equally covers a great diversity of ground, but for present purposes, I will consider it simply as any body of political thought opposed to any of the foundational commitments of liberalism just described. Thus, for example, a system would count as illiberal if it is premised on the inequality of citizens; if it denies the entitlement of the entire populace to rule itself through majority rule; if civil society is understood to be in fact not free

88. In this, it differs considerably from the burst of new electoral regulation law generated over the last few years by Republican-controlled state legislatures, which has been direct and overt in its anti-democratic aims. For an overview, see Gardner, supra note 73, at 897-908, and sources cited therein.

89. See Kagan, supra note 65 , at 10.

90. See generally RosEnBlatT, supra note 65.

91. See generally Robert Filmer, Patriarcha: Or the Natural Power of Kings (1680) (the work that prompted John Locke to develop foundational conceptions of liberalism in his two treatises). See also Arthur O. Lovejoy, The Great Chain of BeIng: A Study OF THE HisTORY OF AN IDEA 242 (1964).

92. See GinsBurg \& HuQ, supra note 68 , at 24.

93. See DiAmOND, supra note 63, at 19.

94. See GinsBurg \& HuQ, supra note 68, at 9 (emphasis omitted).

95. See id.; Juan J. Linz, Totalitarian And Authoritarian Regimes 20, 58 (2000). 
but structured irrevocably by higher laws of religious or traditional origin; and so forth.

At this historical moment, however, the particular strain of illiberalism of greatest concern is "authoritarian populism."96 Populists generally hold that a "true" people, inevitably narrower in scope than the entire population of the state, has lost its rightful control of the state to a corrupt minority. ${ }^{97}$ The solution requires a strong leader with a profound understanding of the true people's needs, 98 who will accomplish their objectives through the accumulation and deployment of immense power that ought not to be restrained by institutional or even democratic checks. 99 Of particular concern here is that "populism is always anti-pluralist"; 100 it denies the plurality of society's members and their interests and beliefs, and thus offers "a phenomenology that involves replacing the whole with one of its parts."101 As a result, "because the people and the leader have effectively merged... the role of deliberation and mediation can be drastically reduced." 102

While we normally associate populism with the representative branches of government - the legislature, and above all, the executive-populist behavior can also be found in the judicial branch. As Professors Anya Bernstein and Glen Staszewski have persuasively demonstrated, populist judging has a distinctive style that, mirroring populist political beliefs, prefers simplicity over complexity; understands and employs "correct" forms of judging, uncorrupted by the influence of untrustworthy elites; and rejects any kind of interpretational or methodological pluralism. 103 Commitments to textualism and originalism, they argue, exemplify the populist style of judging and, in their rejection of practical reasoning, are inherently illiberal and anti-democratic.

\section{A. Beginnings: Liberal and Plural}

\section{The Raw Material of the Constitutional Scheme}

The first and foremost function of a constitution is to create the state104 by establishing institutions, assigning powers, ${ }^{105}$ and in general "defin[ing] the

\footnotetext{
96. NORRIS \& INGLEHART, supra note 4, at 9-12.

97. See MÜLLER, supra note 10, at 22-23; URBINATI, supra note 10, at 77-112.

98. See MÜLLER, supra note 10, at 32-38; URBINATI, supra note 10, at 113-57.

99. See DiAmOND, supra note 63, at 62-63; Lieberman et al., supra note 83.

100. GALSTON, supra note 10, at 127; see MülleR, supra note 10, at 3.

101. URBINATI, supra note 10 , at 13.

102. Id. at 9 .

103. Anya Bernstein \& Glen Staszewski, Judicial Populism, 106 MinN. L. REv. (forthcoming 2021).

104. See Edward Schneier, Crafting Constitutional Democracies: The Politics of Institutional Design 2 (2006); Jeremy Waldron, Constitutionalism: A Skeptical View, in Contemporary Debates in Political Philosophy 267, 273-74 (Thomas Christiano \& John Christman eds., 2009); Ernest A. Young, The Constitution Outside the Constitution, 117 YALE L.J. 408, 412-15 (2007).

105. See Denis J. Galligan \& Mila Versteeg, Theoretical Perspectives on the Social and Political Foundations of Constitutions, in Social AND POLITICAL Foundations OF
} 
structure of the 'normally' functioning state."106 Thus, even before they impose limits on official power, constitutions must "establish institutions that allow people to cooperate and coordinate to pursue projects that they cannot achieve on their own."107 Consistent with this understanding, every constitution the world over devotes considerable attention to the basic structure and operation of the state, including the form of government, and where that form of government is democratic, to the basic practices of democratic self-governance. As Professor Samuel Issacharoff has observed, modern constitutions "[a]lmost invariably ... give express textual protection to democratic processes and to the institutions of democratic politics."'108

The U.S. Constitution is no different. At least a dozen provisions of the original document deal explicitly with the structure of democratic representation (a full inventory of constitutional provisions regulating democratic practice is provided in the Appendix). Article I, Section 2, for example, establishes the system of democratic representation by which the House of Representatives is to be constituted, ${ }^{109}$ sets the qualifications for representatives, and specifies how representation in the House is to be allocated among the states.110 Article I, Section 4 authorizes states to regulate the time, place, and manner of elections for federal office, subject to a congressional override. 111 Another provision prohibits the granting of titles of nobility.112 Several provisions establish mechanisms for selecting the president.113 Another provides that the United States "shall guarantee to every State in this Union a Republican Form of Government."114

Constitutional amendments have more than doubled the number of provisions addressing democratic practice. These provisions revise the mechanisms for selecting presidents and for apportioning representation in the House, and extend democratic methods of selection to the U.S. Senate. 115 They create political rights of free speech, association, and equality; 116 drastically limit the grounds upon which citizens may be disfranchised;117 and grant Congress new powers to police and enforce constitutionalized

Constitutions 3, 6 (Denis J. Galligan \& Mila Versteeg eds., 2013); Keith E. Whittington, The Status of Unwritten Constitutional Conventions in the United States, 2013 ILL. L. REV. 1847, 1855; Young, supra note 104, at 412.

106. Peter C. Ordeshook, Some Rules of Constitutional Design, in LiBERALISM AND THE ECONOMIC ORDER 198, 205 (Ellen Frankel Paul et al. eds., 1993).

107. Jeremy Waldron, Political Theory 34 (2016).

108. Samuel Issacharoff, Fragile Democracies: Contested Power in the Era of CONSTITUTIONAL COURTS 275 (2015).

109. See U.S. ConsT. art. I, $\S 2$, cl. 1 .

110. Id. cls. 2,3 .

111. Id. $\S 4, \mathrm{cl} .1$.

112. Id. $\S 9$.

113. Id. art. II, $\S 1$, cls. 1-4.

114. Id. art. IV, $\S 4$.

115. Id. amend. XII; $i d$. amend XIV, $\S 2 ; i d$. amend XVII.

116. Id. amend. I; id. amend XIV, $\S 1$.

117. Id. amends. XV, XIX, XXIV, XXVI. 
constraints on democratic practice. 118 Nearly thirty provisions, totaling roughly 1855 words - about one-quarter of the document 119 — are devoted to establishing and regulating the practice of representative democracy in the United States.

This body of textual resources, moreover, is supplemented by a rich record of political thought by some of the most original and penetrating political thinkers that the United States has ever produced - a body of thought that many members of the Supreme Court consider themselves obliged to consult in constitutional cases.120 Standard reference documents, such as The Federalist Papers, Madison's notes of the 1787 convention, Farrand's notes of the state ratifying conventions, and the public speeches and private correspondence of the Framers and other prominent individuals of the founding period - to say nothing of the records associated with enactment of the Reconstruction Amendments and later amendments concerning votingrun to many thousands of pages. 121 In sum, there is no shortage of resources available to assist courts in giving meaning to America's commitments to popular sovereignty and democratic self-governance.

\section{The Founding Jurisprudence: Pluralist and Liberal}

The Court initially inserted itself into the field of democratic elections in dramatic fashion. In a pair of cases decided in 1964, Wesberry v. Sanders 122 and Reynolds $v$. Sims, ${ }^{123}$ it held that the method used by the states to draw congressional and state legislative districts was constitutionally defective, thus invalidating at a stroke, as Justice Harlan complained in dissent, "the composition of the House of Representatives"124 as well as that of "all but a few" state legislatures. 125 That is, the Court's rulings held unconstitutional the very makeup of legislative power throughout the length and breadth of the United States.

118. Id. amend. XIV, § 5; id. amend XV, § 2; id. amend XIX, § 2; id. amend XXIV, § 2; $i d$. amend XXVI, $\S 2$.

119. This is assuming the Constitution has a total word count of about 7500 words. See Neil M. Gorsuch, Why Originalism Is the Best Approach to the Constitution, Time (Sept. 6, 2019, 8:00 AM), https://time.com/5670400/justice-neil-gorsuch-why-originalism-is-the-bestapproach-to-the-constitution/ [https://perma.cc/SX7T-TQZD].

120. Justice Scalia, according to his biographer, thought himself the "King of the Originalists." Bruce Allen Murphy, Scalia: A Court of One 415-29 (2008). Other justices have of course announced strong commitments to originalism. See, e.g., Gorsuch, supra note 119 .

121. To give but two examples, the papers of Thomas Jefferson, collected at the University of Virginia, run to forty-three volumes, and those of James Madison run to forty-two volumes so far, with more projected. See James P. McClure \& J. Jefferson Looney, The Papers of Thomas Jefferson, UNIV. OF VA. PRESS, https://rotunda.upress.virginia.edu/founders/ default.xqy?keys $=$ TSJN-print-01\&mode $=$ TOC [https://perma.cc/CB6N-NXU5] (last visited Sept. 17, 2021); Papers of James Madison, Univ. OF VA. ARTs \& SCIENCES, https://pjm.as.virginia.edu/editions [https://perma.cc/SJN5-J994] (last visited Sept. 17, 2021).

122. 376 U.S. 1 (1964).

123. 377 U.S. 533 (1964).

124. Wesberry, 376 U.S. at 20 (Harlan, J., dissenting).

125. Reynolds, 377 U.S. at 589 (Harlan, J., dissenting). 
The Court's methods and reasoning were, in both cases, eclectic, drawing on a great variety of the available interpretive resources and traditions of constitutional interpretation. The majority in Wesberry rested its holding primarily on the language of Article I, Section 2-a structural provisionwhich requires that congressional representatives be chosen "by the People of the several States."126 But the Court drew meaning from this spare provision by resorting to other sources of constitutional meaning. ${ }^{127}$ It examined the deliberations and intentions of the Framers of the Constitution, devoting considerable attention to their understanding of the "rotten boroughs" of England and the historical circumstances of the Great Compromise. 128 It drew on principles of equality, normally associated with the individual rights provisions of the Fourteenth Amendment. 129 It looked for guidance to other structural provisions such as Article I, Section 3 and Article V.130 Most importantly, the Court began to draw from the Constitution, though only insofar as necessary to decision in the case before it, a theory of representative democracy itself - a theory in which, consistent with the fundamental tenets of liberalism, 131 all citizens are deemed equal in their entitlement to participate in whatever processes of governance the people collectively decide to adopt.

The Court deployed the same approach even more forcefully a few months later in Reynolds. There, it relied on many of its own precedents, which it read, collectively, to establish implicitly a constitutionally grounded right to vote. 132 It invoked constitutional text in the form of the Equal Protection Clause. 133 It read Wesberry as identifying a constitutionally embedded "fundamental principle of representative government," which it described as "equal representation for equal numbers of people."134 It brought in principles of due process under the Fourteenth Amendment to help it locate the right to vote among "the basic civil rights of man."135 It further elaborated its emerging theory of democratic representation by declaring unequivocally that "[l]egislators represent people, not trees or acres. Legislators are elected by voters, not farms or cities or economic interests"136 - a position that reads the Constitution as decisively opposed, down to its deepest conceptual roots, to malapportionment. In addition, the Court adverted to the intentions of the Framers.137 It brought in simple

126. U.S. CONST. art. I, § 2; see Wesberry, 376 U.S. at 7-8.

127. See Wesberry, 376 U.S. at 8-17.

128. Id. at $12-17$.

129. See id. at $8-9,11,14,16$.

130. Id. at 13 .

131. See Thomas Hobbes, Leviathan ch. 13 (J. Plamenatz ed., Meridian Books 1963) (1651); John Locke, Second Treatise of Government ch. II, §§ 4-8 (C. Macpherson ed., Hackett Publishing Co., Inc. 1980) (1690). On the influence of Locke in American liberalism, see HARTZ, supra note 2.

132. See Reynolds, 377 U.S. at 554-55.

133. Id. at 557-58.

134. Id. at 560-61.

135. Id. at 561 (quoting Skinner v. Oklahoma, 316 U.S. 535, 536 (1942)).

136. Id. at 562 .

137. See id. at 563-64. 
"logic[]," and reconstructed what it considered to be the "basic aim of legislative apportionment" to flesh out a constitutionally grounded conception of democratic representation. 138 In short, the Court's methods and approach, in the cases that essentially founded the field of constitutional election law, were deeply pluralistic and fundamentally liberal. 139

\section{B. Deconsolidation into Incoherence}

If the U.S. Constitution contains a potentially rich body of resources that might guide courts in the constitutional management of democratic practices, how has the Supreme Court actually proceeded? As this section shows, the Court has slowly narrowed the provisions it considers relevant down to two - twelve words out of nearly two thousand 140 - as its virtually exclusive, all-purpose vehicles for adjudicating constitutional claims involving democratic practice. The following section describes in some detail the Court's present constitutional jurisprudence of democratic practice.

1. The Move to Rights: Three Regimes

The Court's jurisprudence of democracy consists of three major rights regimes that the Court presently uses to adjudicate questions of democratic practice: (1) a jurisprudence founded on the Equal Protection Clause and the Fifteenth Amendment to handle claims of racial discrimination; (2) a right-to-vote jurisprudence grounded in the Equal Protection Clause to handle certain claims of infringement or dilution of the right to vote; and (3) a comparatively newer, rapidly expanding, and increasingly comprehensive First Amendment jurisprudence of speech and association to handle most claims involving infringement of the right to vote as well as virtually all other claims relating to democratic process and procedure.

\section{a. Regime 1: Racial Discrimination}

Not surprisingly, the Court's earliest interventions in the field of democratic practice were precipitated by incidents from the nation's long, ugly history of racial discrimination in politics. It was therefore inevitable that some of the earliest cases to reach the Court in the field of democratic process would involve egregious instances of naked, Jim Crow exclusion. Some cases, for example, raised constitutional challenges to state laws barring Black people from voting through means such as grandfather

138. Id. at 565 .

139. These methods are characteristic of the way constitutional courts around the world handle constitutional issues of democratic practice. See, e.g., ISSACHAROFF, supra note 108, at 194-96 (describing structural jurisprudence of several foreign constitutional courts).

140. The words are: "[E]qual protection of the laws" and "no law abridging the freedom of speech." U.S. CONST. amends. I, XIV. 
clauses ${ }^{141}$ or prohibitions on Black participation in party primaries. ${ }^{142}$ Not surprisingly, the Court turned in such cases to the Constitution's two direct prohibitions of racial discrimination - the Equal Protection Clause of the Fourteenth Amendment, which prohibits racial discrimination generally, and the Fifteenth Amendment, which narrowly targets racial discrimination in voting. Because these amendments offer specialized tools for a highly specific but recurring problem that cuts across every aspect of politics, the Court's reliance on the Fourteenth and Fifteenth Amendments was not merely reasonable, but obvious. As the Court observed in Smith $v$. Allwright, 143 " [i] t may now be taken as a postulate that the right to vote in ... a primary [or] general election is a right secured by the Constitution [which] may not be abridged on account of race."144

In later years, the Court continued consistently to rely on the Fourteenth and Fifteenth Amendments to adjudicate claims that laws regulating democratic practices and processes discriminated on the basis of race. In the seminal, mid-twentieth-century case of Gomillion v. Lightfoot, 145 for example, the Court turned to the Fifteenth Amendment to invalidate an Alabama law that redrew the boundaries of the City of Tuskegee in a way that left every white resident inside the city and virtually every Black resident outside it. 146 In White v. Regester 147 and Mobile v. Bolden, 148 the Court turned to the Fourteenth and Fifteenth Amendments to adjudicate claims that the use of at-large elections discriminated against Black or Latinx people. In a more recent series of cases beginning with Shaw v. Reno, 149 the Court repeatedly invoked the Fourteenth Amendment to analyze claims that redistricting authorities had relied excessively on the race of voters when assigning them to election districts.

Not all constitutional problems with the regulation of politics, however, arise from racial discrimination; in recent years, such claims have formed a distinct minority of election-related litigation. Thus, the pertinent challenge from the point of view of contemporary constitutional law is increasingly how to handle claims involving democratic practices and processes that do not turn on issues of race.150 For those purposes, the Court has developed two additional regimes of rights enforcement.

141. Lane v. Wilson, 307 U.S. 268, 277 (1939); Guinn v. United States, 238 U.S. 347, $347-$ 48 (1915)

142. Terry v. Adams, 345 U.S. 461, 470 (1953); Smith v. Allwright, 321 U.S. 649, 664-65

(1944); Nixon v. Herndon, 273 U.S. 536, 541 (1927).

143. 321 U.S. 649 (1944).

144. Id. at $661-62$.

145. 364 U.S. 339 (1960).

146. Id. at $346-47$.

147. 412 U.S. 755 (1973).

148. 446 U.S. $55(1980)$.

149. 509 U.S. 630 (1993). Shaw was followed by numerous similar cases including Easley v. Cromartie, 532 U.S. 234 (2001); Hunt v. Cromartie, 526 U.S. 541 (1999); Lawyer v. Dep't of Just., 521 U.S. 567 (1997); Bush v. Vera, 517 U.S. 952 (1996); Shaw v. Hunt, 517 U.S. 899 (1996); Miller v. Johnson, 515 U.S. 900 (1995).

150. See, e.g., Case Tracker, ElECTION L. АT ОH. ST. UnIV., https://electioncases.osu.edu/ case-tracker/?sortby=filing_date_desc \&keywords $=\&$ status $=$ all\&state=all\&topic $=25$ 


\section{b. Regime 2: The Equal Protection-Based Right to Vote}

In cases falling outside the realm of racial discrimination, the Court's approach for several decades consisted simply of extending the reach of the Equal Protection Clause to cover new classes of problems as they arose. Many of the earliest cases in this category involved state laws establishing qualifications for voting - literacy, payment of a poll tax, residency, and so forth - that had the effect of excluding the unqualified entirely from the franchise. ${ }^{151}$ Litigants accordingly challenged such laws on the ground that they interfered with a constitutionally grounded right to vote. The Court agreed but, curiously, located the right to vote not in the provisions of the Constitution that speak explicitly of voting-provisions, for example, in Article I and the Seventeenth Amendment establishing an elected House of Representatives 152 and Senate, 153 respectively-but in the Equal Protection Clause, an awkward location that seems far from self-evidently the logical place for a right to vote.

The Court's difficulty in this enterprise, however, was self-created. In its 1874 decision in Minor v. Happersett, 154 a pre-Nineteenth Amendment 155 case in which a female plaintiff challenged a state law restricting the franchise to males, the Court held that "the Constitution ... does not confer the right of suffrage upon any one"156 - that there is, in other words, no federally guaranteed constitutional right to vote. 157 To permit it to evaluate the constitutionality of franchise restrictions without overruling this long-standing precedent, the Court turned to the Equal Protection Clause, reasoning that even though the Constitution does not require states to allow voting at all, or by anyone in particular, a state that does choose to create elections by extending the franchise must do so in a way that comports with the requirements of equal protection. 158 The Court ultimately deployed this

[https://perma.cc/F5WA-LQ9R] (Dec. 31, 2020) (listing major litigation associated with the 2020 elections).

151. Lassiter v. Northampton Cnty. Bd. of Elections, 360 U.S. 45 (1959) (literacy test); Harper v. Va. Bd. of Elections, 383 U.S. 663 (1966) (poll tax); Carrington v. Rash, 380 U.S. 89 (1965) (residency).

152. U.S. CONST. art. I, $\S 2$.

153. Id. amend. XVII, $\S 1$.

154. 88 U.S. 162 (1874).

155. The Nineteenth Amendment prohibits discrimination in voting "on account of sex."

U.S. CONST. amend. XIX

156. 88 U.S. at 178 .

157. The Court's conclusion was a consequence of Article I, Section 4 and Article II, Section 1, which allocate the authority to establish qualifications to vote in federal elections to the states. For further explanation, see James A. Gardner, Liberty, Community and the Constitutional Structure of Political Influence: A Reconsideration of the Right to Vote, 145 U. PA. L. REV. 893, 961-62 (1997).

158. The Court expressed this most clearly in Harris v. McRae:

Although the Constitution of the United States does not confer the right to vote in state elections ... if a State adopts an electoral system, the Equal Protection Clause of the Fourteenth Amendment confers upon a qualified voter a substantive right to participate in the electoral process equally with other qualified voters.

448 U.S. 297, 322 n.25 (1980). 
equal protection-based right to vote in a series of cases adjudicating the constitutionality of exclusions from the franchise based on literacy, 159 residency, ${ }^{160}$ payment of a poll tax, ${ }^{161}$ status as a property taxpayer, 162 and length of residency in the jurisdiction. 163

The pattern pioneered in these voter exclusion cases was soon extended to other kinds of claims. In one line of cases, the Court turned to the Equal Protection Clause and its embedded right to vote in cases involving allegations of vote "dilution" rather than exclusion. Thus, in Reynolds $v$. Sims, the Court invoked the right to vote - a right it characterized as "individual and personal in nature"164 - to invalidate malapportionment of state legislative districts on the ground that the right of voters in overpopulated districts was improperly diluted. It has since applied the one-person, one-vote doctrine identified in Reynolds in many subsequent cases. 165 In another line of cases, since repudiated, the Court extended its equal protection-based voting rights analysis to the adjudication of claims challenging the constitutionality of partisan gerrymandering. 166 In yet another line of cases, the Court applied the same right to vote in cases involving limitations on candidacy, including restrictions on the ability of candidates to get their names listed on the election ballot, 167 age and property qualifications for holding office, 168 and resign-to-run legislation that requires certain incumbents to resign their present office before running for another. 169 Finally and most recently, the Court has applied the equal protection-based right to vote in cases involving election administration, most notably in Bush v. Gore, ${ }^{170}$ where it held that the right to vote is violated when some voters are subjected arbitrarily to substandard procedures for recounting ballots in a contested election. ${ }^{171}$

159. Lassiter v. Northampton Cnty. Bd. of Elections, 360 U.S. 45, 53-54 (1959).

160. Holt Civic Club v. City of Tuscaloosa, 439 U.S. 60, 75 (1978); Carrington v. Rash, 380 U.S. 89, 96-97 (1965).

161. Harper v. Va. Bd. of Elections, 383 U.S. 663, 670 (1966).

162. Kramer v. Union Free Sch. Dist. No. 15, 395 U.S. 621, 632-33 (1969).

163. Dunn v. Blumstein, 405 U.S. 330, 357-60 (1972).

164. 377 U.S. 533, 561 (1964).

165. Some cases have dealt with the range of permissible population variance. Brown v. Thomson, 462 U.S. 835 (1983); Karcher v. Daggett, 462 U.S. 725 (1983); Mahan v. Howell, 410 U.S. 315 (1973). Other cases extended the Reynolds equal protection analysis to various species of special districts. Hadley v. Junior Coll. Dist., 397 U.S. 50 (1970); Cipriano v. City of Houma, 395 U.S. 701 (1969); Avery v. Midland Cnty., 390 U.S. 474 (1968).

166. LULAC v. Perry, 548 U.S. 399, 447 (2006); Vieth v. Jubelirer, 541 U.S. 267, 305-06 (2004); Davis v. Bandemer, 478 U.S. 109, 143 (1986). These cases were repudiated in Rucho, which held partisan gerrymandering claims nonjusticiable. See Rucho v. Common Cause, 139 S. Ct. 2514 (2019).

167. Am. Party of Tex. v. White, 415 U.S. 767, 795 (1974); Lubin v. Panish, 415 U.S. 709, 718-19 (1974); Storer v. Brown, 415 U.S. 724, 746 (1974); Bullock v. Carter, 405 U.S. 134, 149 (1972); Williams v. Rhodes, 393 U.S. 23, 34-35 (1968).

168. See, e.g., Gregory v. Ashcroft, 501 U.S. 452, 472-73 (1991) (upholding law requiring state judges to retire at age 70); Quinn v. Milsap, 491 U.S. 95, 109 (1989) (invalidating property qualification to serve on local government reorganization commission).

169. Clements v. Fashing, 457 U.S. 957, 972-73 (1982).

170. 531 U.S. 98 (2000).

171. Id. at $134-35$. 
In short, beginning roughly with its 1959 decision in Lassiter $v$. Northampton County Board of Elections, 172 which upheld the use of literacy tests, and for several decades thereafter, the Court deployed the right to vote, a right it found embedded implicitly in the Equal Protection Clause, as its primary workhorse in democracy-related cases that did not involve charges of racial discrimination.

The reign of equal protection ended abruptly, however, and it is possible to identify the date with some precision: April 19, 1983. That is the date on which the Court handed down Anderson v. Celebrezze, 173 a case in which the Court refounded the right to vote in the First Amendment freedoms of speech and association, 174 a change that has had enormous - and enormously damaging - consequences for how the Court approaches issues of democratic process.

\section{c. Regime 3: The Catch-All First Amendment}

The newest - and conceptually the narrowest - branch of democratic jurisprudence arises under the First Amendment. The Court's interest in the First Amendment as a tool to regulate electoral politics began routinely enough. In a series of cases decided in the 1960s and early 1970s, the Court confronted a variety of laws imposing direct and overt regulatory constraints on the content of political speech. In New York Times Co. v. Sullivan, 175 for example, the Court invalidated a state libel law that imposed liability on private statements criticizing the performance of public officials so as to protect their reputations from critical public comment.176 The Court invalidated the law as applied to public officials on the ground that the First Amendment forbids state punishment of the "good-faith critic of government."177 In Monitor Patriot Co. v. Roy, 178 the Court extended the reach of the New York Times rule to protect criticism of candidates for elective office, overturning a defamation award in favor of a candidate for U.S. Senate whose character had been impugned by allegations of long-ago criminal conduct. 179

In Mills v. Alabama, 180 the Court struck down a state law prohibiting all "electioneering"- advocating the election or defeat of particular candidates or ballot propositions - on Election Day.181 In Red Lion Broadcasting Co. v. FCC, 182 the Court sustained against a First Amendment challenge a Federal Communications Commission rule requiring broadcast licensees to

172. 360 U.S. 45 (1959)

173. 460 U.S. 780 (1983).

174. Id. at 806 .

175. 376 U.S. 254 (1964).

176. See id. at 292.

177. Id.

178. 401 U.S. 265 (1971).

179. See id. at 277.

180. 384 U.S. 214 (1966).

181. See id. at $216,220$.

182. 395 U.S. 367 (1969). 
provide free equal time to representatives of viewpoints contrary to those presented by the broadcaster. 183 In Miami Herald Publishing Co. v. Tornillo, 184 the Court invalidated a similar right-of-reply law as applied to political attacks appearing in newspapers. 185 All of these cases required the Court to adjudicate the constitutionality of measures that imposed direct regulatory restraints on what individuals were permitted to say in the course of routine political campaigning. There is thus nothing in the slightest surprising or untoward in the Court's resort to the First Amendment to resolve them; it is obviously an appropriate tool for the job.

Things began to change, however, in 1976 when the Court handed down its seminal ruling in Buckley v. Valeo. 186 There, the law under review did not regulate political speech but rather the giving and spending of money used to pay for political speech. ${ }^{187}$ In the Federal Election Campaign Act 188 (FECA), enacted in 1971 and significantly amended in 1974, Congress set ceilings on both monetary contributions to candidates for federal office and independent expenditures in support of such candidates. 189 In a fateful decision, the Court chose to treat these restrictions as abridgments under the First Amendment of the individual freedoms of political speech and political association. 190 Limitations on expenditures made to pay for political speech, the Court held, could not be justified by any sufficiently compelling government interest. ${ }^{191}$ In contrast, the Court ruled, caps on direct financial contributions to candidates could be sustained, notwithstanding their impingement on protected speech and associational interests, in virtue of the government interest in preventing corruption. 192

From here, the First Amendment juggernaut began to gather steam. In its 1983 decision in Anderson v. Celebrezze, the Court took the significant step of essentially firing the Equal Protection Clause as its main constitutional vehicle in cases alleging infringement of the right to vote. ${ }^{193}$ In its place, the Court substituted the First Amendment. Anderson was a ballot access case; the plaintiff, an independent candidate in the 1980 presidential race, challenged Ohio's early filing deadline for independent candidates seeking to be listed on the ballot.194 In a long line of prior cases, the Court had adjudicated the constitutionality of state laws regulating access to the official ballot under the Regime 2 Equal Protection Clause analysis discussed

183. See id. at $387-88$.

184. 418 U.S. 241 (1974).

185. $I d$. at 258 .

186. 424 U.S. 1 (1976) (per curiam).

187. See id. at 15.

188. Pub. L. No. 92-225, 86 Stat. 3 (codified as amended in scattered sections of 18,47 , and 52 U.S.C.).

189. Buckley, 418 U.S. at $1-3,17$.

190. Id. at 17 .

191. Id. at 51 .

192. Id at 35 .

193. See 460 U.S. 780, 792-96 (1983).

194. Id. at 782-83. 
above. 195 In Anderson, however, the Court announced that it would thenceforth analyze ballot access restrictions under the First Amendment right of freedom of association, a second-order right derived by implication from the freedom of speech. 196 The Court's only explanation was buried in a three-sentence footnote:

In this case, we base our conclusions directly on the First and Fourteenth Amendments and do not engage in a separate Equal Protection Clause analysis. We rely, however, on the analysis in a number of our prior election cases resting on the Equal Protection Clause of the Fourteenth Amendment. These cases, applying the "fundamental rights" strand of equal protection analysis, have identified the First and Fourteenth Amendment rights implicated by restrictions on the eligibility of voters and candidates, and have considered the degree to which the State's restrictions further legitimate state interests. 197

Although a restriction on having one's name printed on an election ballot is far from self-evidently a problem that cries out for treatment as a restriction on political speech or association, the Court nevertheless went on in Anderson to invalidate the restriction at issue on the ground that preventing qualified candidates from obtaining a place on the ballot burdened constitutionally protected association between candidates and their supporters. 198

If Anderson had applied only to ballot access cases, its impact might have been slight. In fact, Anderson worked a much more significant and far-reaching doctrinal change: it refounded the right to vote, in virtually all of its applications, from principles of equal treatment to principles of free speech and association. The magnitude of the change became clear only a full decade later when the Court decided Burdick v. Takushi, ${ }^{199}$ a case raising a constitutional challenge to a state law prohibiting write-in voting. 200 Despite its rejection of the plaintiff's free speech argument - that an election ballot should be understood as "a general forum for political expression"201 - the Court nevertheless proceeded under the First Amendment, but on a wholly different theory.

The Court began by addressing itself not to ballot access laws in particular, but to "election laws" in general, a category of laws that, the Court observed, "will invariably impose some burden on individual voters."202 The Court went on to articulate a well-known and now dominant test requiring courts

195. Lubin v. Panish, 415 U.S. 709, 717-19 (1974); Bullock v. Carter, 405 U.S. 134, 149 (1972); Williams v. Rhodes, 393 U.S. 23, 30-35 (1968).

196. See Anderson, 460 U.S. at 806.

197. Id. at 786 n.7. Note that the Fourteenth Amendment is invoked here solely by way of application of the incorporation doctrine through the Due Process Clause; it is not a reference to the Equal Protection Clause.

198. Id. at $792-95,806$.

199. 504 U.S. 428 (1992).

200. Id. at 430 .

201. Id. at 445 (Kennedy, J., dissenting) (describing and agreeing with this aspect of the majority opinion).

202. Id. at 433 (majority opinion). 
"considering a challenge to a state election law" to weigh the burden on a plaintiff's First and Fourteenth Amendment rights against the government's justifications and to apply either strict scrutiny or rational basis review depending on the outcome of that balancing. 203 The result of the Court's analysis in Anderson and Burdick is that all claims alleging infringement of a constitutionally grounded right to vote have been shifted presumptively from the Equal Protection Clause to the First Amendment and that the constitutionally relevant interests of plaintiffs are now redefined from interests in equal treatment to interests in speaking freely and associating. As the Court said plainly in a 2010 case, Burdick "acknowledged the existence of a First Amendment interest in voting,"204 an interest that prior to 1983 had never been acknowledged.

The reach of the Burdick reformulation is readily demonstrated by the great variety of problems to which it has since been applied. The Supreme Court itself has applied Burdick's First Amendment analysis to adjudicate the validity of laws regulating eligibility to vote in party primary elections, 205 the presentation of photo identification at the polls, 206 and disclosure of the identity of initiative petition signers. ${ }^{207}$ Lower courts have dutifully applied Burdick to an even wider variety of problems regarding the availability and conditions of various voting procedures, including procedures for absentee voting, 208 special elections, 209 recall elections, 210 and reruns of invalidated general elections; 211 the qualifications of election officials, including petition circulators, ${ }^{212}$ registrars, ${ }^{213}$ and election inspectors; 214 the technicalities of electoral management, including party nomination procedures, 215 filing fees, 216 the casting and counting of provisional ballots, ${ }^{217}$ early voting,, 218 procedures for counting and verifying referendum petitions, ${ }^{219}$ official

203. See id. at 434 .

204. John Doe No. 1 v. Reed, 561 U.S. 186, 224 (2010) (Scalia, J., concurring).

205. Wash. State Grange v. Wash. State Republican Party, 552 U.S. 442, 452-53 (2008); Clingman v. Beaver, 544 U.S. 581, 602 (2005); Cal. Democratic Party v. Jones, 530 U.S. 567, 572 (2000); Timmons v. Twin Cities Area New Party, 520 U.S. 351, 358-59 (1997). Regulation of party primaries was governed by a First Amendment associational rights analysis even before the decision in Burdick. Tashjian v. Republican Party of Conn., 479 U.S. 208 (1986).

206. See, e.g., Crawford v. Marion Cnty. Election Bd., 553 U.S. 181, 198-204 (2008).

207. See, e.g., John Doe No. 1, 561 U.S. at 186.

208. Price v. N.Y. State Bd. of Elections, 540 F.3d 101, 107-12 (2d Cir. 2008).

209. Monserrate v. N.Y. State Senate, 599 F.3d 148, 156 (2d Cir. 2010).

210. Brassell v. Baker, 805 F. Supp. 925, 927 (M.D. Ala. 1992).

211. Ayers-Schaffner v. DiStefano, 37 F.3d 726, 729-30 (1st Cir. 1994).

212. Maslow v. Bd. of Elections, 658 F.3d 291, 296 (2d Cir. 2011); Nader v. Brewer, 531 F.3d 1028, 1034-35 (9th Cir. 2008).

213. Voting for Am., Inc. v. Steen, 732 F.3d 382, 387-88 (5th Cir. 2013) (alternative analysis).

214. Werme v. Merrill, 84 F.3d 479, 483-84 (1st Cir. 1996).

215. Libertarian Party of Ohio v. Blackwell, 462 F.3d 579, 585 (6th Cir. 2006).

216. Belitskus v. Pizzingrilli, 343 F.3d 632, 643-46 (3d Cir. 2003).

217. Ne. Ohio Coal. for the Homeless v. Husted, 696 F.3d 580, 592-93 (6th Cir. 2012).

218. Obama for Am. v. Husted, 697 F.3d 423, 429-30 (6th Cir. 2012).

219. Lemons v. Bradbury, 538 F.3d 1098, 1103 (9th Cir. 2008). 
practices of reporting vote totals, 220 voter registration and party enrollment practices, 221 vote-counting practices in recall elections, 222 the content of nominating petitions, 223 and designation of party labels on ballots;224 and even the imposition of term limits on candidates for elected office. 225

But the Burdick analysis is not the only vehicle the Court uses to subject democratic procedures to First Amendment review. The Court continues, for example, to apply First Amendment speech analysis to direct restrictions on political speech.226 It applies First Amendment speech and associational analyses to restrictions on the giving and spending of campaign money.227 It invokes the First Amendment right of association to examine laws regulating the activities of political parties.228 It has relied on the First Amendment to adjudicate questions arising from laws requiring disclosure of information about those who speak 229 or give money in the course of political campaigns. ${ }^{230}$ And it has relied on the First Amendment to adjudicate the constitutionality of laws regulating the activities of political actors such as initiative circulators.231 And although before Rucho the Court had consistently applied the Equal Protection Clause in cases raising claims of unconstitutional partisan gerrymandering, ${ }^{232}$ a total of six different justices in various cases asserted that such cases would be more tractable if handled under the First Amendment.233 Before the Court's ruling in Rucho rendered them irrelevant, lower courts had already begun to turn to the First Amendment to resolve partisan gerrymandering claims. 234

To be sure, the Court, for obvious and appropriate reasons, still adjudicates cases involving claims of racial discrimination under the Equal Protection

220. Libertarian Party v. D.C. Bd. of Elections and Ethics, 682 F.3d 72, $73-74$ (D.C. Cir. 2012).

221. Green Party of N.Y. State v. N.Y. State Bd. of Elections, 389 F.3d 411, 419 (2d Cir. 2004).

222. Partnoy v. Shelley, 277 F. Supp. 2d 1064, 1073 (S.D. Cal. 2003).

223. Schulz v. Williams, 44 F.3d 48, 56 (2d Cir. 1994).

224. Libertarian Party of N.H. v. Gardner, 638 F.3d 6, 14 (1st Cir. 2011).

225. Citizens for Legis. Choice v. Miller, 144 F.3d 916, 920-21 (6th Cir. 1998); Bates v. Jones, 131 F.3d 843, 846-47 (9th Cir. 1997).

226. Minn. Voters All. v. Mansky, 138 S. Ct. 1876, 1885 (2018); Burson v. Freeman, 504 U.S. 191, 211 (1992).

227. McCutcheon v. FEC, 572 U.S. 185, 227 (2014); Citizens United v. FEC, 558 U.S. 310, 329 (2010).

228. Eu v. S.F. Cnty. Democratic Cent. Comm., 489 U.S. 214, 222 (1989).

229. McIntyre v. Ohio Elections Comm'n, 514 U.S. 334, 342 (1995).

230. John Doe No. 1 v. Reed, 561 U.S. 186, 194 (2010); Buckley v. Valeo, 424 U.S. 1, 14 (1976).

231. Buckley v. Am. Const. Law Found., 525 U.S. 182, 192 (1999).

232. League of United Latin Am. Citizens v. Perry, 548 U.S. 399, 423 (2006); Vieth v. Jubelirer, 541 U.S. 267, 288 (2004); Davis v. Bandemer, 478 U.S. 109, 118 (1986).

233. See Vieth, 541 U.S. at 314-15 (Kennedy, J. concurring); see also Rucho v. Common Cause, 139 S. Ct. 2484, 2514 (2019) (Kagan, J., dissenting) (joined by Justices Breyer, Ginsburg, and Sotomayor); Gill v. Whitford, 138 S. Ct. 1916, 1938 (2018) (Kagan, J., concurring) (joined by Justices Breyer, Ginsburg, and Sotomayor).

234. League of Women Voters of Mich. v. Benson, 373 F.Supp.3d 867, 912 (E.D. Mich. 2019); Ohio A. Philip Randolph Inst. v. Householder, 373 F.Supp.3d 978, 1073-74 (S.D. Ohio 2019). 
Clause and the Fifteenth Amendment (Regime 1),235 both of which provide specialized tools designed expressly for such controversies. It also continues to use the equal protection-based right to vote (Regime 2) in certain narrow classes of vote dilution cases, such as cases involving apportionment, redistricting, and the one-person, one-vote doctrine. But aside from these exceptions, it is fair to say that the Court now finds the First Amendment (Regime 3) so versatile and appealing a provision that it approaches its democracy cases as though the First Amendment is virtually the only provision in the entire Constitution relevant to the system of representative democracy it institutionalizes. The First Amendment has become for the Court essentially a one-provision constitution, complete in itself, capable of solving nearly every problem of democracy for which judicial review may be had.

\section{The Scholarly Critique}

As this movement in the Court's jurisprudence picked up steam, scholars began to criticize it. Here is where the critique of "incoherence" began to have some bite, although it was made in several different ways. Some scholars, for example, charged the Court with incoherence on an ad hoc basis as a way of arguing that the Court's election law jurisprudence had begun to produce results that in particular cases or domains were so unpredictable or unexpected as to seem essentially random. ${ }^{236}$ Others, however, leveled the charge of incoherence in a broader and more systematic way by arguing that the incoherence of the jurisprudence was a direct consequence of the Court's methodological choice to decide election law issues almost entirely using the vehicle of individual rights. 237 The origins of this "structuralist" critique238 are often traced to an influential 1998 article by Professors Sam Issacharoff and Rick Pildes in which they argued that a jurisprudence based in rights was "too narrow to capture the range of considerations" inherent in the adjudication of issues relating to democratic practice. ${ }^{239}$ The Court's insistence on adjudicating such questions solely through resort to individual rights, they claimed, led to a series of "awkward attempts to fold difficult

235. Cooper v. Harris, 137 S. Ct. 1455, 1463 (2017); Easley v. Cromartie, 532 U.S. 234, 237 (2001); Miller v. Johnson, 515 U.S. 900, 904 (1995); Shaw v. Reno, 509 U.S. 630, 638 (1993).

236. See, e.g., Michael S. Kang, Gerrymandering and the Constitutional Norm Against Government Partisanship, 116 MicH. L. REV. 351, 354 (2017) (Vieth is a "puzzling aberration from the general norm against government nonpartisanship."); Daniel P. Tokaji, Voting Is Association, 43 FLA. ST. U. L. REV. 763, 784 (2016) ("The major problem with the Anderson-Burdick standard ... is that it's unclear exactly what the inquiry into the 'character' of the burden should entail.").

237. See supra note 62.

238. See, e.g., Joseph Fishkin, Equal Citizenship and the Individual Right to Vote, 86 IND. L.J. 1289, 1291 (2011); David Schleicher, Overview: Mapping Election Law's Interior, in Race, Reform, and Regulation of the Electoral Process: Recurring Puzzles in American Democracy 75, 78 (Guy-Uriel Charles, Heather K. Gerken, and Michael S. Kang, eds., 2011).

239. Issacharoff \& Pildes, supra note 62, at 646. 
questions of democratic politics and judicial review into the conventional regime of rights-based constitutional and statutory law."240 That is to say, the Court's approach to a set of critically important constitutional problems was impeded by its "failure to use the proper normative tools." 241 As a result, "the Court's electoral jurisprudence lacks any underlying vision of democratic politics that is normatively robust or realistically sophisticated about actual political practices." 242 In the absence of such an underlying theory or vision of appropriate democratic practice, solidly grounded in constitutional principles, incoherence is said to be the predictable outcome.

In what ways did the Court's jurisprudence of democratic practice seem incoherent? For example, as indicated in Part I, the Court took inconsistent approaches to regulation of political contributions and expenditures, essentially rewriting the Federal Election Campaign Act, a coherent piece of legislation as enacted, into self-contradiction. 243 Or, the Court, seemingly inexplicably, rejected the innovation of the blanket primary. ${ }^{244}$ It startlingly overturned long-standing, widely valued limitations on how candidates may campaign for elective judgeships, ${ }^{245}$ and any form whatsoever of limitation on campaign spending, no matter how benignly motivated. 246

A persistent signal of the growing incoherence of the Court's fully rights-based jurisprudence is that seemingly easy cases suddenly posed great jurisprudential difficulty. A particularly vivid example of this phenomenon, from among many candidates, is the Ninth Circuit's decision in Lindsay $v$. Bowen. 247 Article II of the U.S. Constitution requires the president of the United States to be at least 35 years of age. 248 In Lindsay, a 27-year-old who wished to run for president argued that her exclusion from the California presidential ballot on the ground of age ineligibility violated her First Amendment rights and those of her party and its supporters. On any reasonable view of the matter, this case is resolved completely and decisively by the plain language of a foundational structural provision of the Constitution: Article II. It is hard to understand why any court would even bother to conduct an analysis of such a claim or write a full opinion. Nevertheless, applying what it viewed, not illogically, as binding Supreme Court precedent, the Ninth Circuit turned immediately to the First Amendment claim to analyze the degree to which the constitutional age requirement "burden[s] . . Lindsay's speech and association rights."249 To

240. Id. at 645 .

241. Luis Fuentes-Rohwer, Reconsidering the Law of Democracy: Of Political Questions, Prudence, and the Judicial Role, 47 WM. \& MARY L. REV. 1899, 1946 (2006).

242. Issacharoff \& Pildes, supra note 62, at 646.

243. See Issacharoff \& Karlan, supra note 39 , at 1710-11.

244. See Cal. Democratic Party v. Jones, 530 U.S. 567, 577 (2000).

245. Republican Party of Minn. v. White, 536 U.S. 765, 788 (2002).

246. Ariz. Free Enter. Club's Freedom Club PAC v. Bennett, 564 U.S. 721, 754-55 (2011); Davis v. FEC, 554 U.S. 724, 738-44 (2008).

247. 750 F.3d 1061 (9th Cir. 2014).

248. See U.S. CONST. art. II.

249. Lindsay, 750 F.3d at 1063. 
its credit, I suppose, the court found the burden "minimal" 250 and thus upheld the exclusion, although a better result surely would have been to find the "burden" on the plaintiff's "rights" exactly zero on the ground that a structural provision of the Constitution provides a definitive and fully binding answer to the question posed.

Another easy case that became unnecessarily difficult when handled under a narrow regime of First Amendment rights is Burson v. Freeman, 251 in which the Supreme Court upheld a state law prohibiting electioneering within one hundred feet of polling places. ${ }^{252}$ It is hard to imagine any measure more innocuous than one that requires active campaigning for office to be left outside the polling place itself. Such laws provide voters, at an appropriate moment immediately before casting their ballots, with a brief period of mental repose in which they can compose their thoughts, concentrate on the task at hand, and decide how to discharge the weighty civic duty of voting. 253

At the same time, such laws leave political actors free to campaign in every other place, at every other time, so any loss of opportunity to campaign within, or in the immediate vicinity of, the polling place on Election Day is utterly trivial. Indeed, common sense suggests strongly that the only reason candidates or their supporters would even seek the opportunity to appeal to voters as they enter the polling place or while they vote is not to engage them in a meaningful exchange on the merits of a candidacy but transparently to exploit the possibility that some voters might be influenced to vote for the candidate whose name they have most recently seen or heard, 254 an interest entitled to precisely zero weight in any system that aspires to thoughtful democratic self-rule. Other jurisdictions that no one would consider unfree place considerably greater restrictions on campaigning - New Zealand, for example, prohibits all campaigning on election day, and Spain designates the day before an election an official "day of reflection" on which all campaigning is banned 255 - so the deprivation worked by American electioneering laws again is trivial by comparison.

Nevertheless, the Court found this a difficult case. Because the Court was committed to adjudicating the case under the First Amendment, the facts provided immediate trouble. Electioneering laws not only prohibit speech, but do so in a content-based manner - only campaign speech is prohibitedso the Court found itself compelled by its First Amendment precedents to apply strict scrutiny. ${ }^{256}$ This framework immediately and inappropriately put a strong thumb on the scale in favor of invalidation, 257 and the majority had

\footnotetext{
250. Id.

251. 504 U.S. 191 (1992).

252. See id. at 211.

253. See generally James A. Gardner, Neutralizing the Incompetent Voter: A Comment on Cook v. Gralike, 1 ELECTION L.J. 49 (2002).

254. See id. at 55.

255. GARDNER \& CHARLES, supra note 28 , at 660.

256. See Burson, 504 U.S. at 198.

257. As Justice Holmes once observed, "All rights tend to declare themselves absolute to their logical extreme.” Hudson Cnty. Water Co. v. McCarter, 209 U.S. 349, 355 (1908).
} 
to work far harder than necessary to find a way to uphold the law. In the end, three justices voted to strike down the law on the ground that it engaged in "censorship of election-day campaigning," 258 which is exactly what the law does - a fact that, under any other regime of constitutional analysis, would count as a mark in its favor.

\section{Reconsolidation: The Path to Illiberalism}

Like any weed, authoritarianism thrives in disorderly conditions. ${ }^{259}$ Consequently, one of the first tasks of populist opponents of an established liberal democratic order is to deconsolidate it, sowing the kind of confusion-and associated anxiety-that enhances the appeal of the simplistic, seemingly orderly, but typically illiberal, prescriptions offered by populism. 260 Once an unpleasant sense of chaos and disorder has been established, illiberal actors can much more easily introduce illiberal measures. 261

This is roughly the path pursued by the Supreme Court in its constitutional jurisprudence of democratic practice. If, as I have argued, the Court gradually deconsolidated its constitutional jurisprudence of democratic practice into incoherence, its more recent decisions suggest that the Court has entered a new phase: reconsolidation of a now-wrecked, liberal democratic jurisprudence into an overtly illiberal one. The Court's strategy in this phase appears to have two prongs: First, it has drastically narrowed the class of democratic issues that it construes the Constitution to address, exiling to constitutional oblivion a wide variety of potential claims relevant to the practice of democracy, and remanding to politics abuses that politics is unlikely to correct because it is politics that has generated them. Second, where the Court does construe constitutional rights to address claims regarding democratic practice, it has been highly selective concerning the vigor with which it construes the Constitution to protect the right in question. In some cases, the Court has pushed its increasingly narrow conception of constitutionally protected principles with extraordinary force. In other cases, however, it has taken a remarkably casual approach, finding unobjectionable invasions even of the narrow individual rights it still acknowledges to enjoy constitutional protection. On the whole, these parallel approaches have

258. Burson, 504 U.S. at 218 (Stevens, J., dissenting).

259. See generally KAGAN, supra note 65.

260. Id. at 112, 114 ("To achieve greatness on the world stage, Russia must bring the world back to a past when neither the Russians nor anyone else enjoyed security"; consequently, "Putin has sought to disrupt, divide, and degrade the liberal world order"); see also KAREN Stenner, The Authoritarian Dynamic 71-72 (2005) (individual predispositions to authoritarianism can be triggered by a sense of insecurity, a sense often derived from the routine conditions of liberal democratic politics, i.e., disagreement and partisan bickering); Rachel Marie Blum \& Christopher Sebastian Parker, Trump-ing Foreign Affairs: Status Threat and Foreign Policy Preferences on the Right, 17 PERSPS. ON POL. 737, 739 (2019) (a sense of threat to personal status triggers preferences for illiberal policies).

261. See LEVITSKY \& ZiBLATT, supra note 4, at 95, 192-93 (describing the role of crises in enabling authoritarian leaders). 
produced outcomes that can only be characterized as illiberal and anti-democratic.

\section{Jurisprudential Exile: Narrowing the Field of Relevant Considerations}

One of the Court's principal strategies has been to exclude from judicial consideration-and thus from the purview of the Constitution-an ever-greater variety of claims and considerations. Here, I mention four: (1) an extremely broad and powerful "gag rule" that drastically narrows the vocabulary, and thus the stock of concepts, that litigants may invoke; (2) an informal cap on the number and kinds of rights that the Constitution will be construed to recognize; (3) expansion of the political question doctrine to exclude judicial consideration of challenges to practices that are agreed to be obnoxious to democratic self-rule; and (4) a conception of litigant standing so narrow as to preclude judicial consideration of a growing number of increasingly urgent claims about democratic practice.

\section{a. The Gag Rule}

By far the most significant effect of the Court's turn to individual rights has been the severe narrowing of constitutional discourse that it has produced. It is true, of course, that the Equal Protection Clause and the First Amendment offer litigants a vocabulary and stock of concepts in which to express their claims. Just as important, however, is the vocabulary litigants are now denied. In the absence of availability of any considerations of democratic structure or constitutional telos, litigants challenging manifestly undemocratic practices may not raise an issue of constitutional dimension by arguing, for example, that a law is "undemocratic." They may not argue that a regulatory measure "deprives me of representation," or that it "impairs the democratic accountability of government," or that it undermines "popular sovereignty," or that it makes the government "insufficiently responsive" to the popular will, or that it gives "disproportionate political influence" to a group or to individuals. All of these are prominent and indeed constitutive principles of democracy, however it is conceived,262 yet the Court's jurisprudence of individual rights completely excludes these concepts from judicial consideration; they play literally no role whatsoever in its analysis or decision-making. The Court's conceptual vocabulary thus excludes from the constitutional analysis the very terms and concepts to which people routinely turn when talking about democracy, and which indeed, on any reasonable view of the matter, are inseparable from a meaningful understanding of what democracy is and how it operates. ${ }^{263}$ Indeed, in cases that do not involve

262. The locus classicus is surely LocKE, supra note 131 , ch. II, $\S \S 4-8$, but see also contemporary theorists such as ROBERT A. DAHL, DEMOCRACY AND ITS CRITICS 106-18, 13552 (1989). As Steven Shiffrin has observed, "the First Amendment is interpreted in ways that are at odds with any sensible understanding of democracy." STEVEN H. SHIFFrin, WHAT'S WRONG WITH THE FIRST AMENDMENT? 95 (2016).

263. See generally Dennis Thompson, Just Elections: Creating a Fair Electoral PROCESS In THE United STATES (2002). Relatedly, as Charles Black wrote half a century ago, 
racial discrimination, about all that litigants are now entitled to assert is that some rule or practice impairs their speech or association - by no means a natural or even sensible way to describe many highly significant democratic insults.

Moreover, by choosing to rely almost exclusively in democracy cases on the First Amendment, the Court - several of whose members believe they are compelled to interpret the Constitution by resort to the intentions of the Framers and ratifiers of the Constitution-has cut itself off from an enormously rich body of founding-era political opinion and evidence. The First Amendment is notorious not only for the paucity of its legislative history but also for the acknowledged irrelevance to contemporary problems of such legislative history as exists. 264 Thus, the present jurisprudence disables litigants not only from arguing on the merits that some particular government action is anti-democratic but also that the Framers would so have conceived it.

\section{b. The Rights That Don't Exist}

If a court is going to found a constitutional jurisprudence of democracy exclusively on individual rights, it is surely necessary that the available rights be sufficient in scope and variety to reach the wide variety of abuses of democratic practice that corrupt, self-interested, or single-minded partisan officials might deploy. Yet a remarkable feature of the rights approach is that the number and scope of constitutionally protected democratic rights recognized by the Court is unusually narrow and not at all adequate to the substantial managerial task.

The problems begin with the single most important right in a democratic republic: the right to vote itself. Although the Court has recognized such a right, it has not construed it robustly - that is, the Court has not actually found the right to vote to be affirmatively granted by any provision of the Constitution. Instead, as related above, the Court has found it to exist only indirectly, in two ways. First, the Equal Protection Clause indirectly contains a watered-down, relativistic right to vote. ${ }^{265}$ This right does not acknowledge in any particular class of individuals an actual, affirmative right to cast a ballot in any particular election; instead, it requires only that such opportunities to vote as governments might in their beneficence choose to provide be distributed in a way that is free of prohibited discrimination. 266

excluding considerations of structure from the interpretational resources on which we rely often diverts our attention from more important, if implicit, principles; it "forces us to blur the focus and talk evasively, while the structural method frees us to talk sense." CHARLES L. Black, JR., STRUCTURE AND RElationship in CONSTITUTIONAL LAW 13 (1969).

264. In the words of Robert Bork, one of the founders of the modern originalism movement, "[t]he framers seem to have had no coherent theory of free speech and appear not to have been overly concerned with the subject." Robert H. Bork, Neutral Principles and Some First Amendment Problems, 47 IND. L.J. 1, 22 (1971).

265. See Gardner, supra note 157, at 959-67.

266. See Harris v. McRae, 448 U.S. 297, 322 n.25 (1980) (“Although the Constitution of the United States does not confer the right to vote . . . if a State adopts an electoral system, the 
Second, the right exists indirectly under the First Amendment as something that governments may not excessively burden, 267 but which has no constitutional force or presence independent of the speech and associational interests with which it is indirectly associated. The First Amendment right to vote is thus, in essence, a collection of electrons missing a nucleus.

Similarly, there is no right to run for office.268 In a democratic republic committed to the election of representatives, there must be candidates. States understand this well: state law heavily regulates the conditions under which those interested in public service may stand for elective office.269 When these laws preclude, or place large obstacles in the path of, the candidacy of those who wish to run for elective office, we might expect a commitment to an individual rights approach to produce a constitutionally grounded right to run for office. Yet the Court has consistently refused to admit the existence of such a right. Instead, the Court has adjudicated challenges to restrictions on candidacy indirectly, by treating laws restricting candidacy as though they were laws restricting the right to vote. 270 Indeed, the Court's approach substitutes for one nonexistent right - the right to run for office - a different right - the right to vote - which also lacks direct constitutional grounding.

Similarly, in many cases, the Court has been at pains to point out that the Constitution does not contain a right to proportional representation. ${ }^{271}$ What the Court neglects to mention is that the Constitution, as construed by the Court, does not contain a right even to disproportional representation because the Court has not construed the Constitution to confer a right to any kind of representation at all.272 It is intrinsic to the idea of representative democracy that a democratically elected government ought to be accountable and responsive to the popular will, ${ }^{273}$ but there is no individual or group right to

Equal Protection Clause of the Fourteenth Amendment confers upon a qualified voter a substantive right to participate in the electoral process equally with other qualified voters.").

267. See Burdick v. Takushi, 504 U.S. 428, 432-34 (1992).

268. See, e.g., NAACP v. Jones, 131 F.3d 1317, 1324 (9th Cir. 1997) ("Candidates do not have a fundamental right to run for public office.”); see also Bullock v. Carter, 405 U.S. 134, 142-43 (1972) ("[T]he Court has not heretofore attached such fundamental status to candidacy as to invoke a rigorous standard of review."). This puts the United States at odds with international practice, which recognizes an individual right "to be elected at genuine periodic elections." G.A. Res. 2200A (XXI), United Nations International Covenant on Civil and Political Rights, art. 25(b) (Dec. 16, 1966).

269. See, e.g., N.Y. Elec. LaW § 6-100 (McKinney 2021); CAL. Elect. CodE $\S \S 8000$ 8150 (West 2021).

270. See, e.g., Anderson v. Celebrezze, 460 U.S. 780, 786 (1983) (citing Bullock, 405 U.S. at 143).

271. See, e.g., Rucho v. Common Cause, 139 S. Ct. 2484, 2499 (2019).

272. See Fortson v. Morris, 385 U.S. 231, 234 (1966) (holding that there is no constitutional right to vote for governor).

273. This is true in versions of democratic theory ranging from minimalism, in which accountability is basically the only criterion of whether a system counts as democratic, see Joseph Schumpeter, CAPITAlism, SOCIALISM, AND DemOCRACY 269 (1950); to economic theories, in which policy correspondence to popular preferences is the critical characteristic of democracy, see ANTHONy Downs, An ECONOMIC THEORY OF DEMOCRACY (1957); to classically liberal theories, see LOCKE, supra note 131 ; to the most demanding contemporary theories of deliberative democracy, see Joshua Cohen, Deliberation and Democratic 
accountability or responsiveness. In the same vein, there is no right to register to vote; no right to organize an officially recognized political party; no right of individuals or parties to get their names printed on the ballot; no right to a majoritarian political process; no right to a convenient and accessible polling place, nor any right to enter whatever polling place the state may provide; nor any right to a secret ballot, nor to a secure one. In a jurisprudence in which the Court insists that all constitutional management of democratic practice occur through the adjudication of rights claims, the absence of these rights renders the practice of meaningful democratic self-rule startlingly precarious.

\section{c. The Claims That Don't Exist}

If the Court has narrowed the range of judicially cognizable considerations by capping the number of recognized democratic constitutional rights, it has also done so lately by narrowing the kinds of claims that will be deemed judicially cognizable. By far the most notable example of this is the Court's 2019 decision in Rucho v. Common Cause. ${ }^{274}$ Americans are polarized on many issues, but on the question of partisan gerrymandering they overwhelmingly agree: according to a recent survey, 71 percent of Americans "want the Supreme Court to place limits on lawmakers' ability to manipulate voting maps." 275 In a sharp reversal of four decades of constitutional jurisprudence, the Court in Rucho held that constitutional challenges to partisan gerrymandering by state legislatures raised questions so unsuited for judicial review that they must be deemed fundamentally political rather than judicial.276 As a result, the Court held judicial consideration of partisan gerrymandering claims to lie outside the jurisdiction of federal courts. 277

\section{d. No One Has Standing}

Finally, even when the Court concedes that abuses of democratic norms and practices raise cognizable constitutional claims, the Court increasingly has narrowed the circumstances in which plaintiffs may pursue them by aggressively deploying the Article III jurisdictional requirement of litigant standing. 278 The Court began to deploy Article III to choke off access to the Constitution in democracy cases in United States v. Hays. 279 There, it held

Legitimacy, in The Good Polity: Normative Analysis of the State 17, 17 (Alan Hamlin \& Philip Pettit eds., 1989).

274. 139 S. Ct. 2484 (2019).

275. Kylee Groft, The Results Are In: Most Americans Want Limits on Gerrymandering, CAMPAIGN LEGAL CTR. (Sept. 11, 2017), https://campaignlegal.org/update/results-are-mostamericans-want-limits-gerrymandering [https://perma.cc/7QEZ-CEL2].

276. Rucho, 139 S. Ct. at 2499.

277. Id.

278. For an overview, now unfortunately somewhat out of date, see Saul Zipkin, Democratic Standing, 26 J.L. \& PoL. 179 (2011).

279. 515 U.S. 737 (1995). 
that only people residing physically within a racially gerrymandered district have standing to challenge it, notwithstanding the impact of racial gerrymandering in one district on voters residing within other districts. ${ }^{280} \mathrm{In}$ another redistricting case, the Court held that voters lacked standing to challenge a state legislature's mid-decade redrawing of district lines for partisan advantage. 281 In another, the Court held that a chamber of a state legislature lacked standing to defend its own districting plan against charges of racial gerrymandering, 282 and in another, the Court could not find a proper plaintiff to raise a constitutional claim of partisan gerrymandering. ${ }^{283}$

But many of the standing cases have had nothing to do with redistricting. Thus, for example, the sponsors of a state ballot initiative lacked standing to defend its constitutionality even when state officials refused to do so.284 A candidate for elective judicial office lacked standing to challenge a state law requiring him to be a member of a political party. 285 No one had standing to challenge a policy decision by the Trump administration to exclude from the decennial census count unlawful immigrants residing in the United States, a practice very plausibly alleged to be blatantly unconstitutional. 286

Now, it is certainly possible that some of these lawsuits are not the kind on which federal courts should expend their limited resources, but this is by no means true of all the cases that federal courts are now dismissing on standing grounds. ${ }^{287}$ Moreover, a different way to deter unwanted litigation over democratic procedures would be to develop and apply a robustly democratic jurisprudence that makes clear that anti-democratic laws and practices will not be tolerated under the U.S. Constitution.

\section{Selective Vigor in Deploying Recognized Rights}

In addition to narrowing drastically the range of claims about democratic practice that it deems the Constitution to address and of which federal courts may take cognizance, where the Court still acknowledges a role for the Constitution, it has exercised great selectivity in determining the degree of constitutional protection for interests acknowledged to be of constitutional dimension. In some domains, the Court has pressed narrow rights single-mindedly, and with extraordinary force, to provide highly robust protection to an exceedingly narrow set of interests. In other domains, it has taken a remarkably ho-hum approach, setting levels of constitutional protection at surprisingly low levels.

\footnotetext{
280. See id. at 744-45.

281. See Lance v. Coffman, 549 U.S. 437, 442 (2007).

282. Va. House of Delegates v. Bethune-Hill, 139 S. Ct. 1945, 1949-51 (2019).

283. See Gill v. Whitford, 138 S. Ct. 1916, 1934 (2018).

284. See Hollingsworth v. Perry, 570 U.S. 693, 715 (2013).

285. See Carney v. Adams, 141 S. Ct. 493, 503 (2020).

286. See Trump v. New York, 141 S. Ct. 530, 536-37 (2020) (per curiam).

287. See, e.g., Samuel Issacharoff \& Pamela S. Karlan, Standing and Misunderstanding in Voting Rights Law, 111 HARV. L. REV. 2276, 2287 (1998) (criticizing the result and reasoning of Hays).
} 
By far the most extreme example of the Court pressing narrow rights with great force - and likely the most consequential - is in the domain of campaign finance. There, the Court has applied First Amendment rights of speech and association (Regime 3 ) with great vigor, but in a single direction and against a single target: it has one by one invalidated virtually every conceivable limitation on the ability of political actors to spend money in pursuit of their political objectives. As explained earlier, this line of cases derives from Buckley v. Valeo, in which the Court invalidated regulatory limits on campaign expenditures by individuals and candidates as violations of their rights of speech and association. ${ }^{288}$ Within the last decade, however, the Court has pursued this agenda with unusual energy. In 2010, in Citizens United v. FEC, the Court invalidated a century-old prohibition on corporate political spending from general treasury funds. 289 In so holding, the Court found the interests of corporations in speaking out on political subjects and holding government officials accountable to be heavily burdened by such restrictions, notwithstanding that corporations cannot vote, have no political personality, are more than adequately represented in the political arena by their officers and employees participating in an individual capacity, and had long been permitted to raise money, and spend it without limit in the political arena, through affiliated political action committees. ${ }^{290}$ In so doing, the Court expressly overruled an earlier case, Austin v. Michigan Chamber of Commerce, 291 because a majority in that case had the effrontery to acknowledge that "immense aggregations of wealth" may have "corrosive and distorting effects" on democratic processes and outcomes. 292

The following year, in Arizona Free Enterprise Club v. Bennett, ${ }^{293}$ the Court invalidated a system of public financing for state elections in which candidates facing rich, self-financed opponents were eligible to receive additional public funds to level the playing field.294 Even though, after Buckley, rich, self-financed candidates are free to spend their own money on their own campaigns without limit,295 and the provision at issue was triggered only when candidates competing for the same office were badly mismatched in terms of resources, the Court construed this provision to

288. 424 U.S. 1, 17-23 (1976).

289. See 558 U.S. $310,371-72$ (2010).

290. This resulted from the interaction of the FECA and the Court's ruling in FEC v. National Conservative Political Action Committee (NCPAC), 470 U.S. 480 (1985). Under FECA, 2 U.S.C. $\S 441 \mathrm{~b}(\mathrm{~b})(4)(B)$, corporations, though not permitted to make political expenditures directly out of general treasury funds, were permitted to do so by setting up a captive political action committee (PAC) known as a "separate segregated fund" (SSF). After the Court's ruling in NCPAC, in which the Court invalidated a provision of FECA limiting independent expenditures by PACs, SSFs were permitted to make unlimited independent political expenditures. See 470 U.S. at 501.

291. 494 U.S. 652 (1990).

292. Id. at 684 .

293. 564 U.S. 721 (2011).

294. Id. at $753-55$.

295. See Buckley v. Valeo, 424 U.S. 1, 58-59 (1976). 
impose "an unprecedented" burden on the speech rights of rich candidates. 296 The Court thus seemed to take the position that the rich have the right not only to speak without limitation, but to speak without fear of effective contradiction by the poor.

Three years later, in McCutcheon v. FEC, the Court invalidated an overall spending cap of more than $\$ 123,000$ on contributions to multiple candidates for federal office.297 Despite reaffirming the authority of governments to limit contributions to individual candidates because of their potential to corrupt, the Court found a prohibition on making the maximum contribution to an unlimited number of candidates to be "not a 'modest restraint' at all." 298 Thus, the First Amendment right of rich contributors to support not only candidates who compete to represent them directly, but who compete to represent others with whom the donor shares no political community, nor even any political relationship, cannot be abridged. If, in the 1960s, the Court was able to determine that legislators do not "represent ... trees or acres [or] . . . farms or cities," 299 over the ensuing half-century it evidently figured out what legislators do represent: dollars.

At the same time, where speech and money are not directly at stake, the Court has frequently construed the constitutionally grounded right to vote to offer little protection against government interference. In Crawford $v$. Marion County Election Board, 300 for example, the Court upheld an Indiana law requiring presentation of photo identification as a condition for voting. 301 Indiana justified the law, among the most restrictive in the nation, as necessary to prevent voter impersonation at the polls, even though not a single incident of such fraud had ever been recorded in the state's entire history. 302 The law required eligible voters who lacked one of a limited number of permitted forms of identification to obtain satisfactory ID from a state motor vehicle office, 303 even though such offices were widely scattered in many parts of the state and suitable public transportation was either nonexistent or extremely inconvenient. 304 Obtaining suitable ID also in many cases required a financial outlay that eligible but indigent voters might not be able to afford. 305 In balancing the interests on both sides, the Court found the burden on voters insufficient to outweigh a state justification that was at best speculative, and at worst entirely fraudulent. 306

296. Ariz. Free Enter. Club, 564 U.S. at 736 (quoting Davis v. FEC, 554 U.S. 724, 739 (2008)).

297. See 572 U.S. 185, 194, 227 (2014).

298. Id. at 204 (quoting Buckley, 424 U.S. at 38).

299. Reynolds v. Sims, 377 U.S. 533, 562 (1964).

300. 553 U.S. 181 (2008).

301. See id. at 194, 199-200, 204.

302. Id. at 194 .

303. Id. at 185 .

304. Id. at $212-15$ (Souter, J., dissenting).

305. Id. at 211-18.

306. Lorraine Minnite, The Myth of Voter Fraud 156-57 (2010); CArol Anderson, One Person, No Vote: How Voter Suppression Is Destroying Our Democracy 50-71 (2018). 
Similarly, in Shelby County v. Holder, the Court invalidated section 4 of the Voting Rights Act of 1965 on the ground that the risk of racial discrimination in voting by states subject to the VRA no longer justified the VRA's strict preclearance provisions. 307 Within hours of the ruling, covered states proved the Court wrong by rolling out a wide variety of vote suppression measures. 308 States continued to use their newfound freedom from federal oversight to enact measures harmful to the political participation of Black voters, all the way through the most recent election. ${ }^{309}$

As noted above, during the period when the Court was handing down these decisions, scholars interpreted what they were seeing as jurisprudential incoherence, and understandably so.310 In retrospect, however, it is now clear that the problem with these rulings is not that they are incoherent; it is that they are illiberal. They deny the fundamental political equality of citizens; they deny that the majority presumptively should rule; they repudiate principles of fair and equal representation developed by the Court in its earlier cases; they undermine the possibility of holding officials meaningfully accountable for their actions; and although they acknowledge rights associated with successful democracy, such as rights of free speech and political association, they fail to acknowledge and protect the core interests that these peripheral rights are meant to serve: democratic self-rule by the American polity, in all its messy, pluralistic diversity.

\section{CONCLUSION}

In what is surely one of the greatest ironies of American constitutional law, the U.S. Supreme Court has for a generation or more slowly illiberalized the constitutional jurisprudence of democracy through the exceedingly aggressive deployment of one of the signature devices of liberalism itself: a constitutional right. Long ago, when I was a law student, one often heard it said that law school "sharpens" students by "narrowing" them, a charge meant to imply a warping of the soul. Much the same may be said of the Court's jurisprudence of democratic practice. By continually narrowing the scope of considerations deemed relevant to the constitutionalization of democracy, it has warped the soul of a republican constitution, transforming it into exactly what it is not and was never meant to be: a deeply illiberal document that empowers the powerful and subordinates the weak.

307. See 570 U.S. 529, 547, 557 (2013).

308. See generally Thurgood MArshall Inst. AT NAACP Legal Def. AND EduC. Fund, InC., Democracy Diminished: State and Local Threats to Voting Post-Shelby County, ALABAMA V. HOLDER (2016).

309. For an overview of litigation over voter suppression measures through Election Day 2020, see Joshua A. Douglas, Undue Deference to States in the 2020 Election Litigation (Feb. 4, 2021) (unpublished draft), https://papers.ssrn.com/sol3/papers.cfm?abstract_id=3720065 [https://perma.cc/TCE5-KEMR].

310. See supra notes 55-62 and accompanying text. 


\section{APPENDIX}

\section{Provisions of the U.S. Constitution Relating to Democratic Practice}

1. Art. I, § 2, cl. 1: The House of Representatives shall be composed of Members chosen every second Year by the People of the several States, and the Electors in each State shall have the Qualifications requisite for Electors of the most numerous Branch of the State Legislature.

2. Art. I, $\S 2$, cl. 2: No Person shall be a Representative who shall not have attained to the Age of twenty five Years, and been seven Years a Citizen of the United States, and who shall not, when elected, be an Inhabitant of that State in which he shall be chosen.

3. Art. I, $\S 2$, cl. 3: Representatives ... shall be apportioned among the several States which may be included within this Union, according to their respective Numbers, which shall be determined by adding to the whole Number of free Persons, including those bound to Service for a Term of Years, and excluding Indians not taxed, three fifths of all other Persons. The actual Enumeration shall be made within three Years after the first Meeting of the Congress of the United States, and within every subsequent Term of ten Years, in such Manner as they shall by Law direct. The Number of Representatives shall not exceed one for every thirty Thousand, but each State shall have at Least one Representative; and until such enumeration shall be made, the State of New Hampshire shall be entitled to chuse three, Massachusetts eight, Rhode-Island and Providence Plantations one, Connecticut five, New-York six, New Jersey four, Pennsylvania eight, Delaware one, Maryland six, Virginia ten, North Carolina five, South Carolina five, and Georgia three.

4. Art. I, $\S 2$, cl. 4: When vacancies happen in the Representation from any State, the Executive Authority thereof shall issue Writs of Election to fill such Vacancies.

5. Art. I, $\S 4$, cl. 1: The Times, Places and Manner of holding Elections for Senators and Representatives, shall be prescribed in each State by the Legislature thereof; but the Congress may at any time by Law make or alter such Regulations, except as to the Places of chusing Senators.

6. Art. I, $\S 5$, cl. 1: Each House shall be the Judge of the Elections, Returns and Qualifications of its own Members ...

7. Art. I, $\S 9$, cl. 8: No Title of Nobility shall be granted by the United States ... 
8. Art. II, § 1, cl. 1: [T] ogether with the Vice President, chosen for the same Term, [the President shall] be elected, as follows ...

9. Art. II, § 1, cl. 2: Each State shall appoint, in such Manner as the Legislature thereof may direct, a Number of Electors, equal to the whole Number of Senators and Representatives to which the State may be entitled in the Congress: but no Senator or Representative, or Person holding an Office of Trust or Profit under the United States, shall be appointed an Elector.

10. Art. II, $\S 1$, cl. 3: The electors shall meet in their respective States, and vote by ballot for two Persons, of whom one at least shall not be an Inhabitant of the same State with themselves. And they shall make a List of all the Persons voted for, and of the Number of Votes for each; which List they shall sign and certify, and transmit sealed to the Seat of the Government of the United States, directed to the President of the Senate. The President of the Senate shall, in the Presence of the Senate and House of Representatives, open all the Certificates, and the Votes shall then be counted. The Person having the greatest Number of Votes shall be the President, if such Number be a Majority of the whole Number of Electors appointed; and if there be more than one who have such Majority, and have an equal Number of Votes, then the House of Representatives shall immediately chuse by Ballot one of them for President; and if no Person have a Majority, then from the five highest on the List the said House shall in like Manner chuse the President. But in chusing the President, the Votes shall be taken by States, the Representation from each State having one Vote; A quorum for this Purpose shall consist of a Member or Members from two-thirds of the States, and a Majority of all the States shall be necessary to a Choice. In every Case, after the Choice of the President, the Person having the greatest Number of Votes of the Electors shall be the Vice President. But if there should remain two or more who have equal Votes, the Senate shall chuse from them by Ballot the Vice-President.

11. Art. II, $\S 1$, cl. 4: The Congress may determine the Time of chusing the Electors, and the Day on which they shall give their Votes; which Day shall be the same throughout the United States.

12. Art. IV, § 4: The United States shall guarantee to every State in this Union a Republican Form of Government . . .

13. Amend. I: Congress shall make no law ... abridging the freedom of speech, or of the press; or the right of the people peaceably to assemble, and to petition the Government for a redress of grievances.

14. Amend. XII: The Electors shall meet in their respective states, and vote by ballot for President and Vice-President, one of whom, at least, shall 
not be an inhabitant of the same state with themselves; they shall name in their ballots the person voted for as President, and in distinct ballots the person voted for as Vice-President, and they shall make distinct lists of all persons voted for as President, and of all persons voted for as Vice-President, and of the number of votes for each, which lists they shall sign and certify, and transmit sealed to the seat of the government of the United States, directed to the President of the Senate; - The President of the Senate shall, in the presence of the Senate and House of Representatives, open all the certificates and the votes shall then be counted;-The person having the greatest number of votes for President, shall be the President, if such number be a majority of the whole number of Electors appointed; and if no person have such majority, then from the persons having the highest numbers not exceeding three on the list of those voted for as President, the House of Representatives shall choose immediately, by ballot, the President. But in choosing the President, the votes shall be taken by states, the representation from each state having one vote; a quorum for this purpose shall consist of a member or members from two-thirds of the states, and a majority of all the states shall be necessary to a choice. And if the House of Representatives shall not choose a President whenever the right of choice shall devolve upon them, before the fourth day of March next following, then the Vice-President shall act as President, as in the case of the death or other constitutional disability of the President. The person having the greatest number of votes as Vice-President, shall be the Vice-President, if such number be a majority of the whole number of Electors appointed, and if no person have a majority, then from the two highest numbers on the list, the Senate shall choose the Vice-President; a quorum for the purpose shall consist of two-thirds of the whole number of Senators, and a majority of the whole number shall be necessary to a choice. But no person constitutionally ineligible to the office of President shall be eligible to that of Vice-President of the United States.

\section{Amend. XIV:}

1: All persons born or naturalized in the United States, and subject to the jurisdiction thereof, are citizens of the United States and of the State wherein they reside. No State shall make or enforce any law which shall abridge the privileges or immunities of citizens of the United States; nor shall any State deprive any person of life, liberty, or property, without due process of law; nor deny to any person within its jurisdiction the equal protection of the laws.

2: Representatives shall be apportioned among the several States according to their respective numbers, counting the whole number of persons in each State, excluding Indians not taxed. But when the right to vote at any election for the choice of electors for President and Vice President of the United States, Representatives in Congress, the Executive and Judicial officers of a State, or the members of the Legislature thereof, is denied to any of the male inhabitants of such State, being twenty-one years of age, and citizens of the United States, or in any way abridged, except for participation in rebellion, or other crime, the basis of representation therein shall be 
reduced in the proportion which the number of such male citizens shall bear to the whole number of male citizens twenty-one years of age in such State.

5: The Congress shall have power to enforce, by appropriate legislation, the provisions of this article.

\section{Amend. XV:}

1: The right of citizens of the United States to vote shall not be denied or abridged by the United States or by any State on account of race, color, or previous condition of servitude.

2: The Congress shall have power to enforce this article by appropriate legislation.

17. Amend. XVII: The Senate of the United States shall be composed of two Senators from each State, elected by the people thereof, for six years; and each Senator shall have one vote. The electors in each State shall have the qualifications requisite for electors of the most numerous branch of the State legislatures.

When vacancies happen in the representation of any State in the Senate, the executive authority of such State shall issue writs of election to fill such vacancies: Provided, That the legislature of any State may empower the executive thereof to make temporary appointments until the people fill the vacancies by election as the legislature may direct.

This amendment shall not be so construed as to affect the election or term of any Senator chosen before it becomes valid as part of the Constitution.

18. Amend. XIX: The right of citizens of the United States to vote shall not be denied or abridged by the United States or by any State on account of sex.

Congress shall have power to enforce this article by appropriate legislation.

19. Amend. XXIII:

1: The District constituting the seat of Government of the United States shall appoint in such manner as the Congress may direct: A number of electors of President and Vice President equal to the whole number of Senators and Representatives in Congress to which the District would be entitled if it were a state, but in no event more than the least populous state; they shall be in addition to those appointed by the states, but they shall be considered, for the purposes of the election of President and Vice President, to be electors appointed by a state; and they shall meet in the District and perform such duties as provided by the twelfth article of amendment.

2: The Congress shall have power to enforce this article by appropriate legislation. 
20. Amend. XXIV:

1: The right of citizens of the United States to vote in any primary or other election for President or Vice President, for electors for President or Vice President, or for Senator or Representative in Congress, shall not be denied or abridged by the United States or any state by reason of failure to pay any poll tax or other tax.

2: The Congress shall have power to enforce this article by appropriate legislation.

21. Amend. XXVI:

1: The right of citizens of the United States, who are eighteen years of age or older, to vote, shall not be denied or abridged by the United States or any state on account of age.

2: The Congress shall have the power to enforce this article by appropriate legislation. 